Boise State University

ScholarWorks

Civil Engineering Faculty Publications and

Presentations

7-20-2011

Relating Climatic Attributes and Water Resources Allocation: A Study Using Surface Water Supply and Soil Moisture Indices in the Snake River Basin, Idaho

David J. Hoekema

Boise State University

Venkataramana Sridhar

Boise State University 


\title{
Relating climatic attributes and water resources allocation: A study using surface water supply and soil moisture indices in the Snake River basin, Idaho
}

\author{
David J. Hoekema ${ }^{1}$ and Venkataramana Sridhar ${ }^{1}$ \\ Received 28 June 2010; revised 15 April 2011; accepted 5 May 2011; published 20 July 2011.
}

[1] Climate change forced by anthropogenic activities has been ongoing since at least the beginning of the industrial revolution. Part of the recent warming in the western United States has been attributed to anthropogenic climate change. This research seeks to answer the basic question of how declining streamflow, increasing temperatures, and fluctuation in precipitation have impacted water resource allocation in the Snake River Plain over the past 35 years (1971-2005). Understanding how changes in climatic attributes have historically impacted water allocation should help water managers better understand how projected climate change may influence allocation. Annual and monthly diversion trends from 62 locations in the Snake River Plain were compared to temperature and precipitation trends at 10 climate stations across the basin. We found a strong trend of declining annual surface water diversions across the study area. Of the 62 diversion points examined, 45 have highly significant decreasing annual diversion trends, while an additional 8 have significant decreasing trends. Despite the annual decline in surface water diversions, April diversions have increased at more than half of the diversion points, with 15 locations showing highly significant trends and an additional 17 showing significant increasing diversion trends.

A comparison of diversions to the Surface Water Supply Index indicates that the decline in midseason and late season diversions is mostly caused by decreasing supply in the study period, while a comparison of diversions to Palmer's $Z$ index and the Standardized Precipitation Index indicates that early season diversions are highly correlated to early season moisture anomalies.

Citation: Hoekema, D. J., and V. Sridhar (2011), Relating climatic attributes and water resources allocation: A study using surface water supply and soil moisture indices in the Snake River basin, Idaho, Water Resour. Res., 47, W07536, doi:10.1029/2010WR009697.

\section{Introduction}

[2] Toward the beginning of the industrial revolution, Tyndall [1861] discovered that carbon dioxide had the ability to trap heat in the atmosphere. Callendar [1938] was able to calculate using a simple physics model that rising temperatures since the beginning of the 1900s might have been forced by industrial emissions of carbon dioxide. As carbon dioxide and other greenhouse gases have increased in the atmosphere global temperatures continue to rise [Bates et al., 2008]. There have been many studies conducted throughout the western United State on climate impacts [Nash and Gleick, 1991; Barnett and Pierce, 2009; Cayan et al., 2008; Miller et al., 2009] and in the Northwest in particular [Hamlet and Lettenmaier, 1999; Payne et al., 2004; Markoff and Cullen, 2008] that seek to provide water managers a better understanding of what the future may hold. For instance, Barnett and Pierce [2009] study on sustainable deliveries in the Colorado River basin and

\footnotetext{
${ }^{1}$ Department of Civil Engineering, Boise State University, Boise, Idaho, USA.
}

Copyright 2011 by the American Geophysical Union. 0043-1397/11/2010WR009697
Markoff and Cullen [2008] research on the impacts of climate change on hydropower production in the Pacific Northwest, have focused on the supply side of water resource management. However, climate change may not only impact water supply, it may also impact demand. The advance of the growing season [Christidis et al., 2007] may result in a shift in timing of demand [Kenney et al., 2008].

[3] Detection and attribution studies conducted with global climate models (GCMs) provide strong evidence that the rise in temperature in the western United States and resulting hydrologic changes have been forced, at least in part, by anthropogenic factors, mainly by emissions from the consumption of fossil fuel [Bonfils et al., 2008; Barnett et al., 2008]. These detection and attribution studies indicate that human-induced climate change has resulted in the lengthening of the growing season [Christidis et al., 2007], decrease of mountain snowpack [Pierce et al., 2008], and earlier timing of spring runoff [Hidalgo et al., 2009] in the western United States. Barnett et al. [2008] estimate that $60 \%$ of the hydrologic change in the western United States is human-induced while the rest is due to natural climatic variability.

[4] Natural climatic variability in the western United States is thought to mainly be caused by the interaction of the El Nino-Southern Oscillation (ENSO) [Rasmusson and 
Table 1. Significance and Magnitude of Streamflow Decline Since 1967 Using the Mann-Kendall Nonparametric Trend Test ${ }^{\mathrm{a}}$

\begin{tabular}{lcc}
\hline \multicolumn{1}{c}{ Stream } & $p$ Value & $\begin{array}{c}\text { Rate of Change } \\
(\% / \mathrm{yr})\end{array}$ \\
\hline Buffalo Fork near Moran, WY & 0.028 & -0.78 \\
Cache Creek near Jackson, WY & 0.017 & -1.12 \\
Greys River near Alpine, WY & 0.074 & -0.75 \\
Big Lost River near Chilly, ID & 0.018 & -1.19 \\
Bruneau River at Rowland, ID & 0.212 & - \\
Boise River near Twin Springs, ID & 0.257 & - \\
S. F. Boise River near Featherville, ID & 0.135 & - \\
Mores Creek above Robie Creek, ID & 0.212 & - \\
S. F. Payette River at Lowman, ID & 0.141 & - \\
L. F. Payette River at McCall, ID & 0.189 & - \\
Weiser River near Weiser, ID & 0.522 & - \\
\hline
\end{tabular}

${ }^{\mathrm{a}}$ See Clark [2010].

Carpenter, 1982] and the Pacific Decadal Oscillation (PDO) [Zhang et al., 1997]. The main impact of these oscillations is on wintertime precipitation. Brown and Comrie [2004] show that the Snake River basin tends to have a dipole behavior in relation to ENSO during the warm and cool phases of the PDO. During the warm phase of the PDO a fall El Nino tends to be followed by a wetter than average winter, and a fall La Nina is followed by drier than usual winter. The relationship between ENSO and PDO is then reversed during a cool PDO. Research by Cook et al. [2007] and Seager [2007] indicates that all persistent droughts in the western United States originate when sea surface temperatures in the Pacific are anomalously cold or in a la Niña like condition, as is the case with the turn of the century drought which first impacted the surface water supply in the Snake basin in 2001 according to the Surface Water Supply Index estimates of drought on the Boise River and Snake River below Hesie (see http://www.id.nrcs.usda.gov/snow/ watersupply/swsi-main.html). Most of the study period is dominated by a predominately warm phase of the PDO which started in 1977 and continued until 1998. The period from 1998 to 2005 is marked by an indistinct PDO signal that was mostly cool from the summer of 1998 to the summer of 2002 after which the signal switched back to warmer conditions. Because the study period of this research is dominated by one phase of the PDO we will not explore ENSO-PDO relationships to demand.

[5] While we cannot distinguish directly how much of the recent climate change in the Snake River basin is human induced or the product of natural climate variability, we believe it is critical to identify how surface water irrigators' demand for water has changed under historic climate conditions. The findings presented here should provide water managers and irrigators a better understanding of how projected climate change may impact water resource management in the basin. Our focus in this paper is to investigate how water demand has been impacted by the changes in climatic attributes, specifically in terms of streamflow, temperature, precipitation, evapotranspiration (ET), and soil moisture in the Snake River basin between 1971 and 2005. Clark [2010] has shown a significant decline in unregulated streamflow throughout most of the Snake River basin between 1967 and 2007. The decline in streamflow has been stronger in the eastern portion of the basin than in the western portion. The only river that did not show a signif- icant decline in streamflow was the Weiser River located in the western basin (see Table 1). Figure 1 shows the decadal variability of streamflow at four locations included in Clark's study. Figure 1 indicates increasing variability in annual streamflow throughout the last century and a declining trend in average decadal streamflow from the 1970s through the 2000s.

[6] While streamflow, temperature, and precipitation data are readily available from climate stations across the basin long-term spatially distributed soil moisture records and long-term actual ET measurements are nonexistent within the basin. While we would have liked to include ET and soil moisture in our trend analysis, we choose to perform a trend analysis only on measured climatic attributes and not modeled attributes. One issue with indentifying long-term trends using modeled data is that the results may be biased by the model, as Bormann [2011] pointed out in a study on longterm ET trends in Germany using 18 potential ET models. Since there are no long-term ET and soil moisture records in the basin, we do not include a trend analysis of these attributes. Also we would not expect to find significant trends in soil moisture impacting diversions since the purpose of
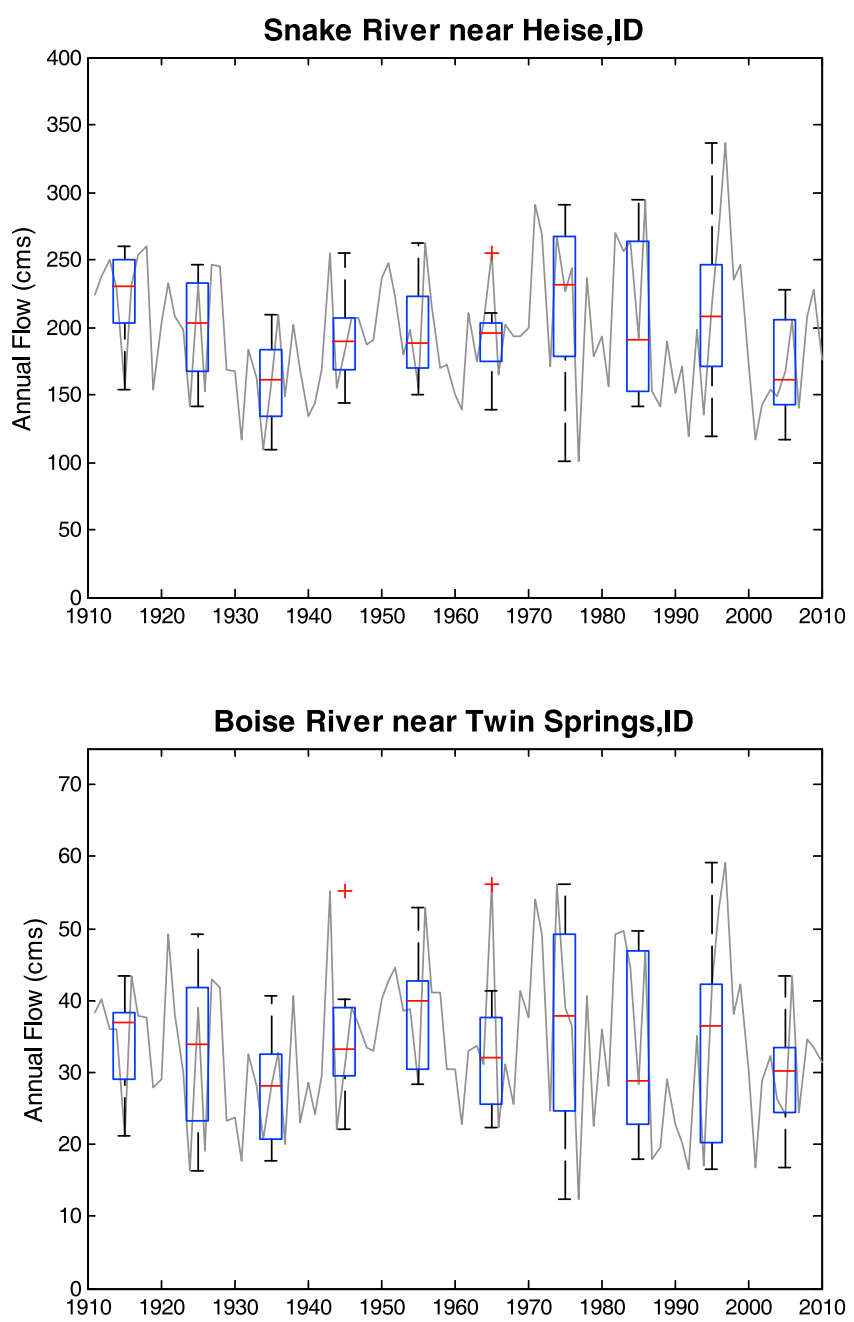

Figure 1. Decadal comparison of streamflow at two locations in Idaho: (a) naturalized annual streamflow of the Snake River at Heise and (b) unregulated flow of the Boise River at Twin Springs (following Clark [2010]). 
surface water diversions is to maintain soil moisture. The only time soil moisture should impact diversions is at the beginning of the irrigation season. Therefore we decided to analyze how climatic attributes might influence early season irrigation through use of the Palmer Drought Severity Index (PDSI) and Palmer's $Z$ index [Palmer, 1965]. PDSI uses temperature, precipitation, and the soil's available water capacity to estimate soil moisture conditions. The $Z$ index, used to calculate PDSI, is a measure of the departure of the monthly climate from normal moisture conditions. Because the $Z$ index is not a measure of soil moisture, but the departure of climate from normal moisture conditions, the $Z$ index is thought to be a better measure of short-term or agricultural drought than PDSI [Karl, 1986; Quiring and Papkryiakou, 2003]. An abbreviated summary of PDSI and the $Z$ index calculations is contained in section 4. The Standardized Precipitation Index (SPI) [McKee et al., 1993, 1995] was also correlated against diversions to determine the role of precipitation anomalies in early season diversions.

[7] Our study includes a trend analysis of surface water diversions from more than 62 locations throughout southern Idaho during a 35 year period from 1971 to 2005. Some of the 62 diversion locations represent multiple canals, while other locations represent individual canals. Although diversion records extend back to 1928 throughout most of the basin, we chose to limit our analysis to 1971, because many of the large water resource infrastructure projects, that affect irrigation reliability, were completed prior to that date. A list of all the canals represented in the study can be found in Appendix A. Following the trend analysis, we compare the historic diversions to the Natural Resource Conservation Service's (NRCS) Surface Water Supply Index (SWSI), the Palmer Drought Severity Index (PDSI), and Palmer's $Z$ index [Palmer, 1965]. SWSI was developed to estimate the surface water supply available to water users, while PDSI has been used as a proxy for soil moisture conditions [Dai et al. 2004]. Both indices provide strong representation of the 1977 drought, the late 1980s drought, and the turn of the century droughts 1999-2005.

[8] Since the quantity of surface water irrigation diversions is controlled both by the need to maintain adequate soil moisture and the amount of water supply available, these indices when compared against diversions provide a clear picture of how surface water irrigation varies at the monthly time scale due to changes in temperature, precipitation, natural streamflow and reservoir storage. Although PDSI and the $Z$ index have been frequently used in climate change studies to understand how projected temperature and precipitation changes may impact the frequency and severity of drought [Cook et al., 1999, 2007; Dai et al., 2004; Hoerling and Eischeid, 2007; Woodhouse et al., 2009], it has never, to our knowledge, been used to study how surface water users respond to climatic changes. More information on these indices can be found in section 4 . We plan to use the findings in this research in ongoing research assessing projected climate change impacts on agricultural surface water supply within the Snake River basin.

[9] While the focus of this paper is on how changes in climatic attributes have impacted diversions it is important to briefly consider two other important trends that may influence diversions: (1) increased irrigation efficiency during the period of study and (2) land use changes. Beginning in the 1970s many surface water irrigators began switching from flood and furrow irrigation to sprinkler irrigation to conserve water [Johnson et al., 1999]. Sprinkler irrigation is more efficient than flood or furrow irrigation, which tend to provide the crop with excess water. The excess water either percolates into the aquifer or is lost to a drainage ditch. While such conversions would intuitively seem to lead to a decline in demand, since the same amount of land could be irrigated with less water, we did not find this to be necessarily true in the comparison of diversions to the SWSI index. In some cases water conservation through sprinkler irrigation may have allowed irrigators to increase the amount of acreage under irrigation or allow for cultivation of more water intensive crops. A review of county and district level crop statistics using the United States Department of Agriculture's (USDA) National Agricultural Statistics Services QuickStats 1.0 Web site (see www.nass. usda.gov) reveals that Idaho's major crops (potatoes, sugar beets, wheat, hay, corn, and dairy) do not follow climatic patterns during the period from 1971 to 2005. During this period there was a consistent trend of increasing irrigated acreage of hay and wheat as well as increased acreage of sugar beets and potatoes (both irrigated crops) that peaked during the 1990s (a decade that started under drought conditions). For example from 1972 and 1992 irrigated wheat acreage increased nearly fourfold from 120,000 acres to 420,000 acres in Ada, Canyon, Gooding, Jerome, Lincoln, Bingham, Jefferson, and Madison counties, while sugar beets (an irrigated crop) in south central Idaho expanded from 170,000 to 200,000 acres. The rapidly growing production of dairy products starting in the early 1990s and corn in the late 1990s in Idaho are clearly driven mainly by nonclimatic forces, most likely market trends. Since land use patterns do not appear to be influenced strongly by climate we have ignored them in this study.

[10] The structure of the paper is as follows. Section 2 provides background information on geographic and climatic characteristics of the study area. Section 3 describes how diversions are represented in the current planning and management of water resources by the Idaho Department of Water Resources (IDWR). Section 4 provides a description of the Mann-Kendall nonparametric statistical trend test and how the test was used to detect trends in diversions and historic climate change, our data sources, and a brief description of how surface water diversions were correlated to SWSI, PDSI, and Palmer's $Z$ index. Section 5 presents the results of the trend and correlation analyses, section 6 covers the discussion of the results, and section 7 provides some conclusions drawn from this research.

\section{Study Area}

[11] The Snake River Plain is a broad plain formed by the passage of the North American tectonic plate over the Yellowstone hot spot [Mabey, 1982; Smith, 2004]. The portion of the Snake River basin that supplies irrigation to the plain is about $190,000 \mathrm{~km}^{2}$ (based on USGS estimated watershed above the Hell's Canyon Dam gage 13290450). Most of the surface of the central portion of the eastern Snake River Plain is covered by deep layers of volcanic rock. The most recent flows remain exposed, while older flows are covered by a thin layer of soil [Kjelstrom, 1995]. While there are pockets of agriculture on the northern side of plain where fluvial deposits from mountain streams have 


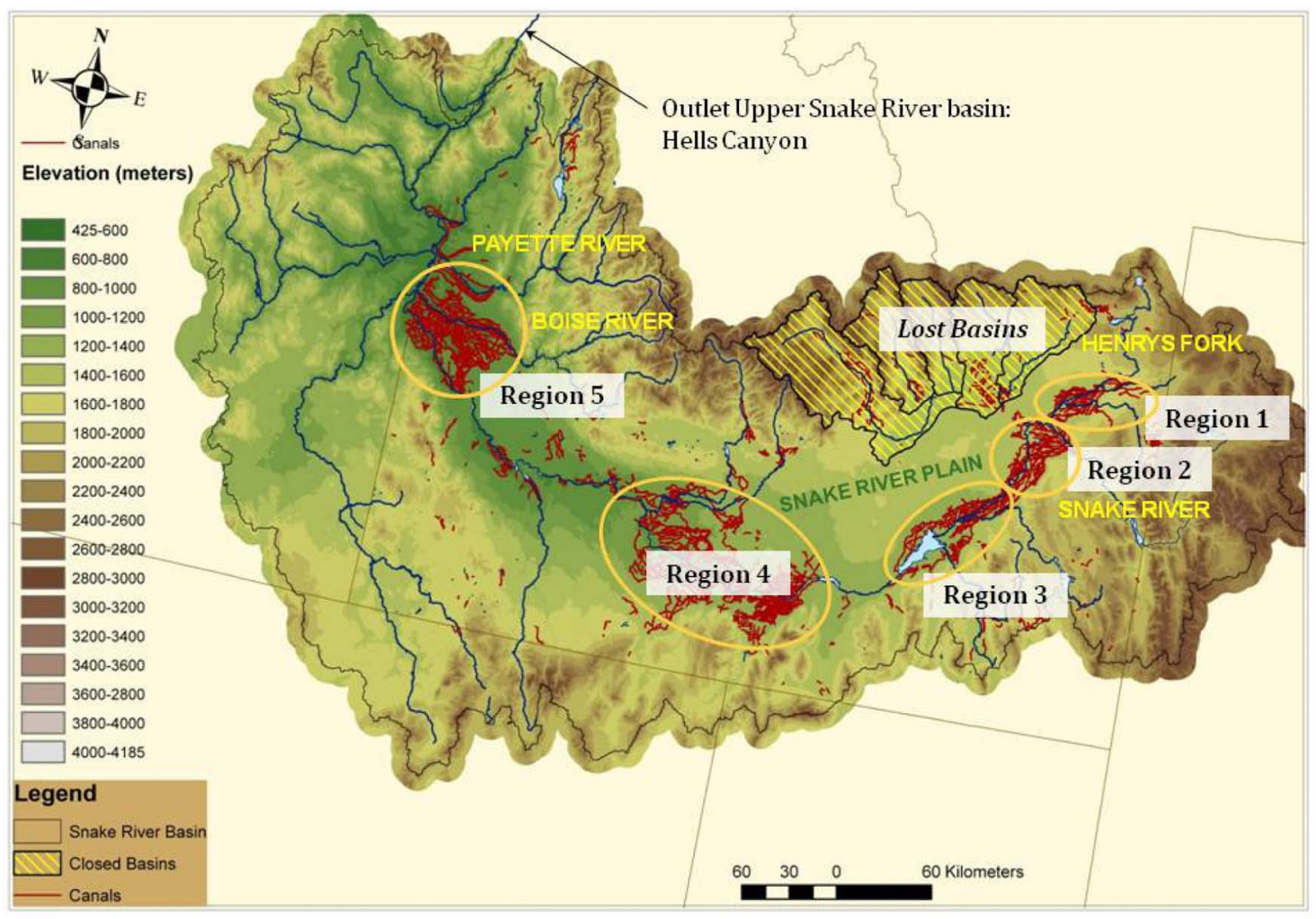

Figure 2. Study area: Snake River basin upstream of Hells Canyon in southern Idaho located between $41.5^{\circ} \mathrm{N}-45.5^{\circ} \mathrm{N}$ and between $110.0^{\circ} \mathrm{W}-119.0^{\circ} \mathrm{W}$.

accumulated over the volcanic rock, the bulk of Idaho's agriculture, and the surface water diversions examined here, are located in five regions along the southern fringe of the plain adjacent to the Snake River, as shown in Figure 2 with rivers in blue and canals in deep red. The first agricultural region, in the far eastern portion of the plain, is supplied by irrigation water from Henrys Fork, Falls River, and Teton River. The second agricultural region is located mainly on the south side of a large bend in the Snake River between Heise and Idaho Falls. Surface water irrigation for this region is mainly diverted from Willow Creek and the Heise to Lorenzo reach of the Snake River. The third agricultural region, to the east and north of the American Falls Reservoir, is supplied by diversions from the Lorenzo to Blackfoot reach of the Snake River and the Blackfoot River. The fourth region is located mainly between Rupert and King Hill. Irrigation for the fourth region is diverted from the Blackfoot to Milner reach of the Snake River. Discharge from the East Snake Plain Aquifer through natural springs located beneath American Falls Reservoir provides an additional $71 \mathrm{~m}^{3} / \mathrm{s}$ of surface water to this reach of the river [Kjelstrom, 1995]. The fifth and western most agricultural region diverts its surface water supply mainly from the Boise and Payette rivers.

[12] Elevations in the plain vary from about $620 \mathrm{~m}$ in the west to around $1,800 \mathrm{~m}$ in the east. The climate is semiarid with most portions of the plain receiving between 150 and $300 \mathrm{~mm}$ of rain annually. Precipitation in the plain follows a general east-west gradient with the east receiving more moisture. Natural vegetation is composed mostly of bunchgrass and sagebrush, with willows and cottonwoods growing along stream channels. To our knowledge, the local atmospheric interactions caused by dense agricultural clusters in the midst of a vast semiarid plain are not well understood. Alfaro et al. [2005] suggests that a spring soil moisture feedback exists in the Snake River Plain, in which low spring soil moisture translates to hotter, drier summer conditions with increased groundwater pumping. Since irrigated agriculture maintains relatively consistent soil moisture during the irrigation season, the feedback must be based on increased sensible heat flux from the surrounding nonirrigated arid plain. During dry years more of the incoming radiation in the nonirrigated regions would be converted to sensible rather than latent heat flux. Also temperature, advection due to wind, and humidity may increase the vapor moisture deficit at the plant-soil-atmospheric interface leading to greater ET.

[13] Without irrigation agriculture would be very limited in the Snake River Plain. July precipitation at the 10 climate stations used in this study averages $13 \mathrm{~mm}$ during the study period from 1971 to 2005. Precipitation in the western plain peaks during the winter and during both the winter and spring in the eastern plain.

\section{Background: Current Representation of Diversions in Water Resource Planning and Management}

[14] Idaho irrigation rights are administered according to the Priority Doctrine, in which those with the oldest water rights are given first priority to water during times of shortage [Slaughter, 2004]. There are two types of water 


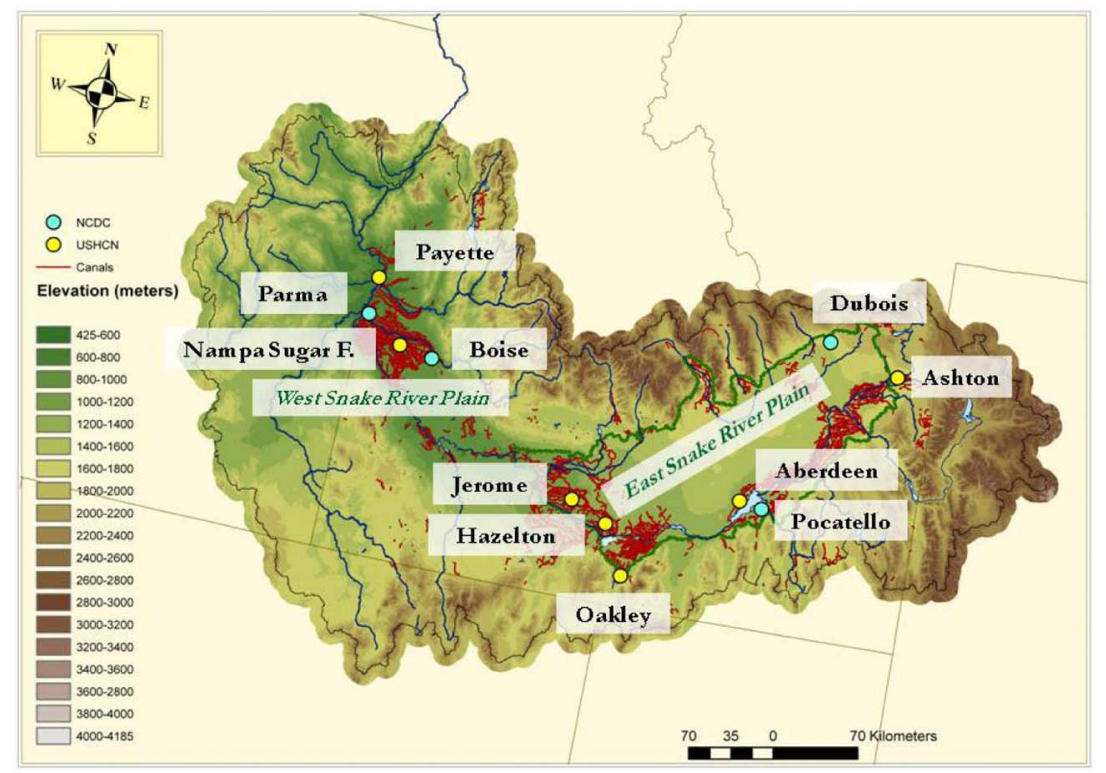

Figure 3. Location of climate stations in the Snake River Plain with yellow stations based on USHCN data set and cyan stations based on NCDC data set.

rights that impact surface water irrigation in Idaho: natural flow and storage rights. Natural flow refers to the water that would be in the river if no water was stored in the reservoirs. Natural flow rights are measured either by flow rate or by both flow rate and volume. Storage rights are measured by volume, and represent water stored in reservoirs.

[15] Idaho farmers generally determine the amount of land and type of crops planted each season based on carryover storage and the streamflow forecast, made available before the growing season [Pierce et al., 2010]. Streamflow forecasts indicate the amount of natural flow that will be available and whether reservoirs will be able to fill. Carryover refers to storage water not used in the previous irrigation season.

[16] The Idaho Department of Water Resources (IDWR) is responsible to administer water rights within the state. During the irrigation season, IDWR operates a daily accounting model that keeps track of both natural flow and storage rights. In addition to the accounting model, they also have developed the Snake River Planning Model (SRPM), which has been used to plan water management in the state for over 30 years [Idaho Water Resources Board, 1972]. The purpose of the model is to guarantee that proposed changes in water management do not limit water users' historic access to water. Changes in water management are applied to the model which is then run over the historic period to see if the proposed change would result in decreased diversions. If the new management results in decreased diversions, the new management strategy must be revised until no new shortages occur. A shortage in the SRPM model is thus defined as a loss in a user's historic access to water, or a decline in diversions. In this paper we will refer to this type of shortage as a planning shortage. It is possible that a planning shortage may not occur even during the worst drought, as long as historic delivery is maintained. In some extreme cases, the historic delivery may have been zero, and therefore no matter what change in management occurs there will never be a planning shortage. For example, during the drought period in 1992, a canal company that relies on natural flow rights may not have been able to divert water late in the season because their water rights were junior to those of other users. Although the farmers relying on diversions from this canal may have experienced crop failure, they still received their full water right based on the priority of their right and from a water resource allocation perspective no shortage occurred. Since this model was developed to guarantee that historic delivery is maintained, this definition of a planning shortage is perfectly valid when actual diversions are applied.

[17] Because diversion practices have changed over time as arable acreage increased, some land was taken out of production, storage was increased or decreased and irrigation practices and rights changed, IDWR can only realistically guarantee present users historic access to water based on the present conditions of infrastructure, land use and water rights. In order to model the present condition of the system under historic climate, IDWR chose to represent diversions in the SRPM model by actual monthly diversions over the last 15 years (1991-2005) and then represent historic diversions as the average monthly diversion during the 1991-2005 period. This present conditioning of the past, assumes that diversions over the last 15 years are a reasonable representation of current demand. However, it is likely that this average diversion value may be biased to under predict demand because the recent 1991-2005 average occurs during a period in which the Snake River Plain has undergone two of the most extensive multiyear droughts of the century. As measured by SWSI, drought occurred from 1987 to 1994, and from 2000 to 2005 (it should be noted that this drought continued until the beginning of the irrigation season in 2010, in some portions of the basin) in most of the Snake River basin. Seven out of 9 and 6 out of 10 drought years since 1960 have occurred within the period from 1991 to 2005 according to the 1 April SWSI on the 
Table 2. Climate Station Location, Elevation, and Instrumented Record

\begin{tabular}{lccc}
\hline \multicolumn{1}{c}{ Station } & Location & $\begin{array}{c}\text { Elevation } \\
\text { (feet) }\end{array}$ & $\begin{array}{c}\text { Record } \\
\text { NCDC }\end{array}$ \\
\hline Ashton 1N & $44.0^{\circ} \mathrm{N}, 111.3^{\circ} \mathrm{W}$ & 5212 & 1948 -present \\
Dubois Exp. Stn. & $44.2^{\circ} \mathrm{N}, 112.2^{\circ} \mathrm{W}$ & 5450 & 1948 -present \\
Pocatello 2NE & $42.9^{\circ} \mathrm{N}, 112.4^{\circ} \mathrm{W}$ & 4832 & 1956 -present \\
Aberdeen Exp. Stn. & $43.0^{\circ} \mathrm{N}, 112.8^{\circ} \mathrm{W}$ & 4402 & 1948 -present \\
Oakley & $42.2^{\circ} \mathrm{N}, 113.9^{\circ} \mathrm{W}$ & 4559 & 1948 -present \\
Hazelton & $42.6^{\circ} \mathrm{N}, 114.1^{\circ} \mathrm{W}$ & 4060 & 1948 -present \\
Jerome & $42.7^{\circ} \mathrm{N}, 114.5^{\circ} \mathrm{W}$ & 3740 & 1948 -present \\
Boise Air Terminal & $43.6^{\circ} \mathrm{N}, 116.2^{\circ} \mathrm{W}$ & 2814 & 1898 -present \\
Nampa Sugar Factory & $43.6^{\circ} \mathrm{N}, 116.6^{\circ} \mathrm{W}$ & 2470 & 1976 -present \\
Payette & $44.1^{\circ} \mathrm{N}, 116.9^{\circ} \mathrm{W}$ & 2150 & 1948 -present \\
\hline
\end{tabular}

Boise River and Snake River. These droughts would have limited the water available for diversion during the present condition, the average diversion from 1991 to 2005 may not represent what could have been legally diverted under more favorable hydrologic conditions. Therefore decisions made based on average diversions (1991-2005) could reduce users' historic access to water. While this study provides a basic understanding of how climate impacts diversions on the Snake River which is critical to understanding climate change in the basin, the study also helps define a more realistic method for determining a shortage for use in the SRPM model under historic and projected climate.

\section{Methods and Materials}

[18] The methods used to conduct this research include a nonparametric trend test of monthly diversions, temperature, and precipitation from 62 diversion locations and 10 climate stations within the Snake River basin, as well as, a comparison of surface water diversions to SWSI, PDSI, Palmer's $Z$ index, and SPI. This section of the paper contains two subsections describing first the trend analysis (section 4.1) and then the comparison of diversions to the three indices (section 4.2).

\subsection{Mann-Kendall Nonparametric Trend Analysis}

[19] The detection of trends in canal diversions, precipitation, and temperature were based on the Mann-Kendall nonparametric statistical trend test [Mann, 1945; Kendall, 1975]. The test is based on the null hypothesis that there is no significant increasing or decreasing trend in the data over time. When the probability of the null hypothesis is less than $30 \%(p<0.30)$ we assume the trend is significant. If the probability of the null hypothesis is less than $10 \%(p<$ $0.10)$ the trend is considered highly significant. The choice of significance levels is consistent with Clark's [2010] trend analysis for unregulated streamflow in Idaho, western Wyoming, and northern Nevada. The data set used for the trend analysis of canal diversions was provided by IDWR. Seven climate stations were selected for analysis of temperature and precipitation trends from the United States Historical Climatological Network's (USHCN) database (see www.ncdc.noaa.gov/oa/climate/research/ushen). The location of these stations is shown as yellow dots in Figure 3, while location and elevation are listed in Table 2. A review of USHCN stations in Idaho, using the surfacestations.org Web site reveal that most of the stations in Idaho have poor exposure. The two stations with the best exposure, used in this analysis, the Aberdeen Experiment Station, has a lilac bush too close to the station, and the Oakley weather station is located within a grassy area that appears to have a house and tree that might bias its temperature measurements. While the poor exposure of many weather stations has called into question the reliability of the U.S. climatological record [Fall et al., 2011; Pielke et al., 2007]. Research by Menne et al. [2010] indicates that poor citing tends to result typically an artificial cool bias in maximum temperature and a warm bias in minimum temperature. All trends discussed in this paper from the USHCN Version 2 historic data set have been corrected for time of observation bias, discontinuities (including urbanization effects), and missing values. Comparison of "raw" and corrected data at Oakely, Jerome, and Aberdeen weather stations indicates that the corrected data typically reduce the observed warming trend. More details on the USHCN data set can be found at the Web site mentioned above. An additional three COOP stations (shown in Figure 3 as cyan dots) representing "raw" climate data were also analyzed (data were downloaded from www.ncdc.noaa.gov/oa/ climate/stationlocator.html). These COOP stations were chosen because they represent the only complete monthly temperature and precipitation records in the Snake River basin over the study period.

[20] Diversions records were provided to us by IDWR, which as far as we could determine, does not maintain records on the uncertainty of canal diversions. IDWR's records are highly variable in quality. The State of Idaho does not require any specific instrumentation, and some canals are measured only once a week. Typically quality of the data declines based on the size of the canal, with diversion records on smaller canals being the least accurate (L. Cresto, personal communication, 16 March 2011). Some of the largest canals (79 canals) in the system are monitored through the Hydromel program, run by the Bureau of Reclamation. Diversions in the Hydromet program are measured every 15 min (realtime data are available at www.usbr.gov/pn/hydromet/idwd. html) as close as possible to the head gates, with records being sent remotely to the Bureau's Boise office. In order to avoid bias from poor record keeping related to small canal diversions, we performed trend analysis at both the division level and the reach level and for all canals with annual diversions exceeding $1.2(10)^{8} \mathrm{~m}^{3}$ (or 100,000 acre-feet). For conciseness we only report results of diversions based on the sum of all diversions in a climate division and individual canals. The diversion trends along the Snake River reported within this paper are all based on canals included in the highquality Hydromet monitoring system. The four individual canal diversion trends presented on the Boise and Payette Rivers represent the two largest diversions in each system.

\subsection{Surface Water Supply Index Correlation to Canal Diversions}

[21] As mentioned earlier, diversions in Idaho are regulated by natural flow and storage rights. Both annual streamflow and storage are included in SWSI. The streamflow used in the SWSI index represents unregulated flow below the lowest reservoir and above most irrigation diversions. SWSI is a monthly index that ranks each year in the index based on available supply. Supply is the sum of the previous month's reservoir storage and the naturalized flow through the remainder of the irrigation season which ends in 


\section{August}

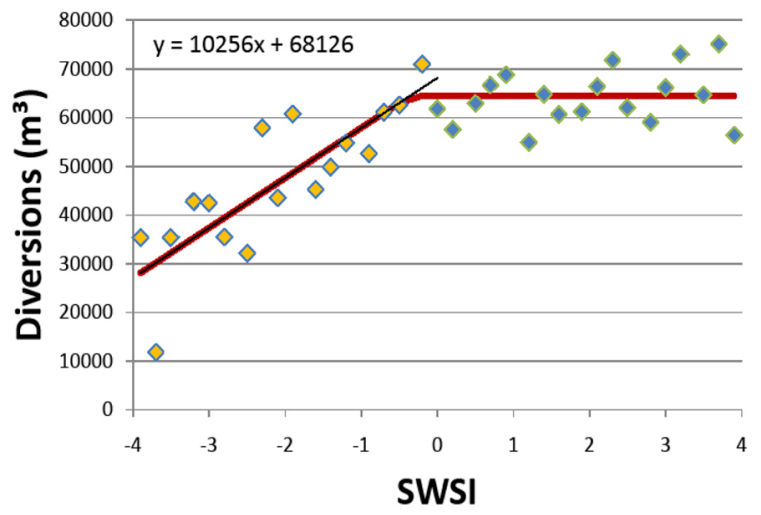

Figure 4. August diversions from 1971 to 2005 correlated with August SWSI on the Burgess Canal.

September. SWSI values range from -4 for the year with the least supply to 4 for the year with greatest supply.

[22] In this study we recalculated SWSI for the Henry's Fork, Snake River below Heise, Boise River, and Payette River for the period between 1971 and 2005 and then plotted diversions versus SWSI. The recalculation involved reranking the years to match the diversion data which end in 2005. Monthly diversions are plotted on the $y$ axis with SWSI values for each month on the $x$ axis (see Figure 4). A piecewise function is used to correlate supply with diversions during the mid and late irrigation season. The first leg of the piecewise function rises along with supply until a breakpoint is reached. After the breakpoint the slope on the second leg of the piecewise function is zero. During dry years the amount of water a canal company can divert is limited by the amount of water available in the river and the priority of their water right. As flows increase the canal company can continue to divert more water until they reach the limit of their need or water right. The piecewise function indicates that surface water irrigation diversions are driven by supply rather than demand. The objective of the piecewise function is to minimize the root mean square error (RMSE). An example of this correlation is shown in Figure 4 for the month of August on the Burgess Canal which diverts water from the Heise to Lorenzo reach of the Snake River. The yellow points in Figure 4 represent the points that correspond to the rising limb of the piecewise function while the blue points represent the zero slope portion of the piecewise function.

\subsection{PDSI, Palmer $Z$ Index, and SPI Correlation to Canal Diversions}

[23] In addition to comparing diversions to SWSI we also analyzed the correlation of diversions to the Palmer Drought Severity Index (PDSI), Palmer's $Z$ index, and SPI using the Spearman Rank correlation coefficient [Spearman, 1904]. PDSI measures the departure of soil moisture from normal conditions, the $Z$ index measures the departure of monthly climate from normal moisture conditions, and SPI is a measure of just the precipitation anomaly. The use of PDSI in this analysis is limited because the analysis focuses on subseasonal response of irrigators monthly climate anoma- lies. The advantage of SPI in relation to either PDSI or the $Z$ index is that it is much easier to calculate and understand since it simply calculates the departure of precipitation from an average condition based on a probability distribution [Guttman, 1998]. The disadvantage of SPI when compared to the more complex $Z$ index, is that SPI does not consider how changes in evapotranspiration, runoff, and soil water loss influence drought.

[24] The discussion below provides an abbreviated summary of how the PDSI and $Z$ index are computed. PDSI was developed by Palmer [1965, p. 3] as a means of determining not only the severity of drought but also the beginning and ending of drought. PDSI is calculated using a simple twolayer soil moisture model. Palmer defines drought as “....an interval of time, generally on the order of months or years in duration, during which the actual moisture supply at a given place rather consistently falls short of the climatically expected or climatically appropriate supply."

[25] Palmer [1965, p. 3] then goes on to define the severity of drought as "...being a function of both the duration and magnitude of the moisture deficiency." PDSI has been criticized because it lacks a snow algorithm [Dai et al., 2004] and the soil moisture model is fairly crude. For example evaporation from the soil column occurs at the potential rate, which is calculated empirically using Thornthwaite's [1948] method, and all moisture in the first $25 \mathrm{~mm}$ soil layer must be removed before moisture is lost from the underlying layer which grossly simplifies soil moisture transfer [Alley, 1984]. PDSI is also sensitive to the calibration period [Karl, 1986] and by construct responds slowly to precipitation changes [Karl, 1986, Guttman, 1998]. Despite its weaknesses, Palmer's index has withstood the test of time, and is currently the most widely used method for determining drought [Wang et al., 2009].

[26] Palmer's $Z$ index used to calculate PDSI by representing the monthly departure of soil moisture conditions from normal can also be used to measure drought. The advantage of the $Z$ index is that it is less dependent on the calibration period and responds rapidly to climatic anomalies at the monthly time step [Karl, 1986]. The calculation of the $Z$ index (Z) is summarized below: The calculation of $Z$ includes both the monthly departure of precipitation from climatically appropriate conditions, $d$, such that

$$
Z=d K
$$

where

$$
d=P-\hat{P}
$$

where $\hat{P}$ is calculated based on estimated monthly evapotranspiration $(\widehat{\mathrm{ET}})$, recharge $(\hat{R})$, runoff $(\widehat{\mathrm{RO}})$, and soil water loss $(\hat{L})$ such that

$$
\hat{P}=\widehat{\mathrm{ET}}+\widehat{\mathrm{RO}}+\hat{R}-\hat{L}
$$

and the coefficient $\mathrm{K}$ is a constant determined by historic climate conditions. PDSI is then calculated as:

$$
\operatorname{PDSI}_{i}=\operatorname{PDSI}_{i-1}+1 / 3 Z_{i}-0.103\left(\operatorname{PDSI}_{i-1}\right)
$$




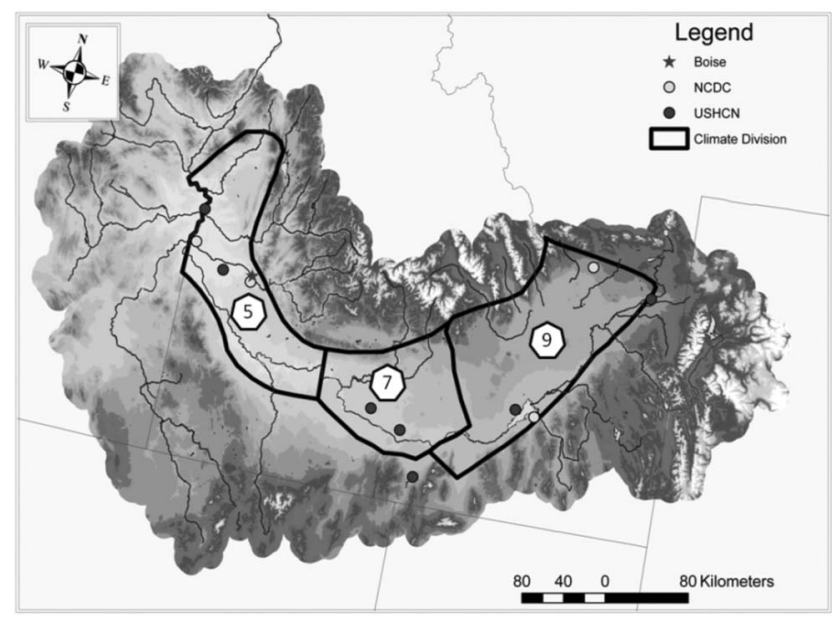

Figure 5. Three NCDC climate divisions within the Snake River basin.

Because the $Z$ index, like PDSI, considers both temperature and precipitation it has been found to have superior performance in dry climates when compared against SPI [Quiring and Papkryiakou, 2003]. The sensitivity of the $Z$ index to both temperature and precipitation anomalies is documented by Hu and Willson [2000].

[27] Historic monthly PDSI, $Z$ index, and SPI data can be downloaded from the NCDC Web site (www1.ncdc.noaa. gov/pub/data/cirs/) representing instrumental data from 1895 to the present. The data are organized by state and climate division. In this research we used both PDSI and $Z$ index for the 5th, 7th, and 9th climate divisions in Idaho (see www.ncdc.noaa.gov/climate-monitoring/). These climate divisions are also referred to as the Western Valleys, Central Plains, and Upper Snake River divisions and are shown in Figure 5. The PDSI, $Z$ index, and SPI values are based off temperature and precipitation data weighed equally for all stations within the climate division. In this study we compared the correlation of the sum of all Boise River diversions (except the New York Canal) to PDSI values for climate division 5; the sum of all Blackfoot to Milner diversions on the Snake River were compared to climate division 7 PDSI; and the sum of all Heise to Blackfoot diversions on the Snake River were compared to climate division 9 PDSI. Although Heise to Lorenzo diversions occur in climate division 10 , they correlate better with climate division 9 PDSI. The better correlation to division 9 is due to the fact that climate division 10 represents a mountainous region, while the diversions analyzed occur in the Snake

Table 3. Significance and Magnitude of Monthly, Annual, and Seasonal Temperature Trends as Well as the Average Temperature at 10 Climate Stations in the Snake River Basin From 1971 to $2005^{\mathrm{a}}$

\begin{tabular}{|c|c|c|c|c|c|c|c|c|c|c|c|c|c|c|c|c|c|}
\hline Climate Station & Jan & Feb & Mar & Apr & May & Jun & Jul & Aug & Sep & Oct & Nov & Dec & Year & DJF & MAM & JJA & SON \\
\hline \multicolumn{18}{|c|}{ Significance } \\
\hline Dubois $^{b}$ & ++ & + & ++ & ++ & & & + & + & + & & & & ++ & ++ & ++ & + & + \\
\hline Ashton & ++ & & ++ & ++ & + & & + & & + & & & + & ++ & ++ & ++ & ++ & + \\
\hline Oakley & ++ & & ++ & ++ & ++ & & ++ & ++ & ++ & ++ & & & ++ & + & ++ & ++ & ++ \\
\hline Pocatello $^{\mathrm{b}}$ & + & & & ++ & + & & & & & & & & + & & ++ & & \\
\hline Aberdeen & + & & ++ & ++ & ++ & & + & ++ & ++ & ++ & & & ++ & + & ++ & ++ & ++ \\
\hline Hazelton & ++ & & ++ & ++ & + & & + & & + & & & + & ++ & ++ & ++ & ++ & + \\
\hline Jerome & ++ & & ++ & ++ & & & + & ++ & ++ & + & & & ++ & + & ++ & ++ & ++ \\
\hline Boise $^{b}$ & + & & ++ & + & + & & ++ & ++ & ++ & & & & ++ & + & ++ & ++ & + \\
\hline Nampa & ++ & & ++ & + & & & + & + & ++ & ++ & & + & ++ & ++ & + & + & ++ \\
\hline Payette & ++ & & ++ & & & & ++ & + & + & ++ & ++ & ++ & ++ & ++ & ++ & ++ & ++ \\
\hline \multicolumn{18}{|c|}{$\Delta\left({ }^{\circ} C\right)$} \\
\hline Dubois $^{\mathrm{b}}$ & 3.7 & 1.5 & 3.1 & 2.4 & & & 1.2 & 1.2 & 1.5 & & & & 1.6 & 2.4 & 2.2 & 0.8 & 1.0 \\
\hline Ashton & 3.3 & & 2.9 & 2.6 & 1.5 & & 0.8 & & 1.3 & & & 2.0 & 1.4 & 2.1 & 2.3 & 0.6 & 0.6 \\
\hline Oakley & 3.0 & & 2.8 & 2.0 & 1.6 & & 2.5 & 2.3 & 2.5 & & & & 1.7 & 1.3 & 2.2 & 1.6 & 1.7 \\
\hline Pocatellob & 2.7 & & & 1.1 & 0.9 & & & & & & & & 0.6 & & 1.3 & & \\
\hline Aberdeen & 3.6 & & 2.1 & 1.9 & 1.8 & & 1.4 & 1.5 & 2.3 & 1.4 & & & 1.6 & 1.9 & 2.0 & 1.0 & 1.6 \\
\hline Hazelton & 3.2 & & 2.7 & 1.7 & 1.4 & & 2.0 & & 2.3 & & & 1.0 & 1.6 & 1.4 & 1.9 & 1.5 & 1.4 \\
\hline Jerome & 3.2 & & 2.1 & 1.8 & & & 1.3 & 1.6 & 1.8 & 1.4 & & & 1.3 & 1.5 & 1.6 & 0.9 & 1.2 \\
\hline Boise $^{b}$ & 2.9 & & 2.1 & 1.5 & 1.3 & & 2.2 & 2.2 & 2.5 & & & & 1.5 & 1.6 & 1.6 & 1.7 & 1.2 \\
\hline Nampa & 3.8 & & 2.2 & 1.1 & & & 0.8 & 1.2 & 2.1 & 1.7 & & 2.1 & 1.4 & 2.3 & 1.2 & 0.6 & 1.5 \\
\hline Payette & 3.8 & & 2.0 & & & & 1.7 & 1.3 & 1.9 & 1.8 & 1.3 & 2.4 & 1.5 & 2.4 & 1.0 & 1.1 & 1.7 \\
\hline \multicolumn{18}{|c|}{ Average Temperature $\left({ }^{\circ} \mathrm{C}\right)$} \\
\hline Dubois $^{\mathrm{b}}$ & -6.7 & -4.5 & 0.2 & 5.9 & 11.0 & 15.7 & 20.4 & 19.7 & 14.3 & 7.6 & -1.0 & -6.2 & 6.4 & -5.8 & 5.7 & 18.6 & 7.0 \\
\hline Ashton & -7.2 & -5.0 & -0.5 & 4.9 & 10.0 & 14.2 & 17.8 & 17.0 & 12.1 & 6.2 & -1.6 & -6.7 & 5.1 & -6.4 & 4.8 & 16.4 & 5.6 \\
\hline Oakley & -1.9 & 0.5 & 4.3 & 4.6 & 11.9 & 16.5 & 20.6 & 20.2 & 15.3 & 9.6 & 2.7 & -1.5 & 8.8 & -1.0 & 7.9 & 19.1 & 9.2 \\
\hline Pocatello b & -4.4 & -1.7 & 3.3 & 7.6 & 12.2 & 16.9 & 21.2 & 20.5 & 15.1 & 8.7 & 1.3 & -3.7 & 8.1 & -3.3 & 7.7 & 19.6 & 8.4 \\
\hline Aberdeen & -5.3 & -2.8 & 2.6 & 7.0 & 11.6 & 16.0 & 19.9 & 19.1 & 13.6 & 7.7 & 0.5 & -4.7 & 7.1 & -4.3 & 7.1 & 18.4 & 7.3 \\
\hline Hazelton & -2.8 & -0.1 & 4.6 & 8.2 & 12.7 & 17.6 & 21.8 & 20.8 & 15.3 & 9.3 & 2.2 & -2.3 & 8.9 & -1.8 & 8.5 & 20.1 & 8.9 \\
\hline Jerome & -2.3 & 0.4 & 5.1 & 9.1 & 13.5 & 18.4 & 22.9 & 22.2 & 16.6 & 10.6 & 3.0 & -1.9 & 9.8 & -1.3 & 9.3 & 21.2 & 10.1 \\
\hline Boise $^{b}$ & -1.1 & 2.3 & 6.4 & 10.0 & 14.5 & 19.2 & 23.6 & 23.0 & 17.6 & 11.2 & 4.0 & -0.8 & 10.9 & 0.0 & 10.3 & 22.0 & 10.9 \\
\hline Nampa & -1.4 & 2.2 & 7.0 & 10.6 & 15.2 & 19.7 & 23.9 & 22.8 & 17.1 & 10.8 & 3.7 & -0.9 & 10.9 & -0.1 & 10.9 & 22.1 & 10.5 \\
\hline Payette & -2.1 & 1.9 & 7.0 & 10.6 & 15.2 & 19.5 & 23.6 & 22.6 & 17.2 & 10.8 & 3.7 & -1.2 & 10.7 & -0.6 & 10.9 & 21.9 & 10.6 \\
\hline
\end{tabular}

${ }^{\mathrm{a}}$ For diversions, ++ represents a highly significant increase in diversions $(p<0.10)$. DJF, December-January-February; MAM, March-April-May; JJA, June-July-August; SON, September-October-November.

${ }^{\mathrm{b}}$ Trends represented by these stations are based on "raw" NCDC data, not trend-corrected USHCN data. 


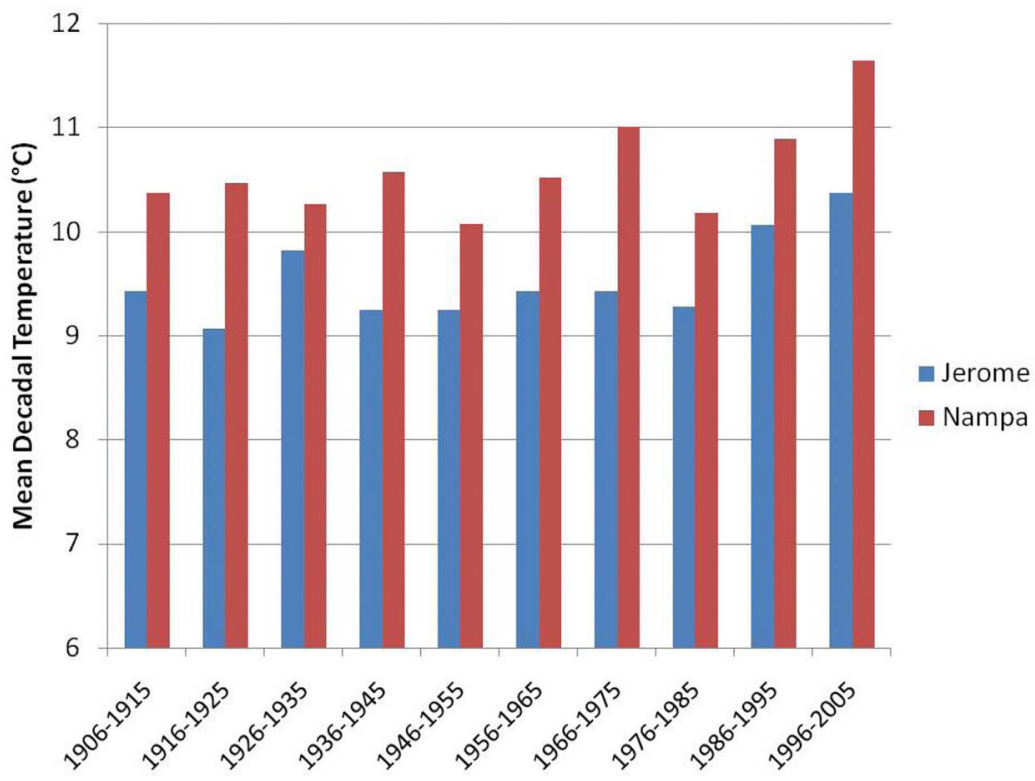

Figure 6. Decadal average annual temperature at the Jerome and Nampa Sugar Factory weather stations based on the USHCN data set.

River Plain immediately adjacent climate division 9, which represents most of the eastern Snake River Plain.

\section{Results}

[28] The results of the research are presented in sections 5.1 and 5.2. First we present the results of the trend analysis for canal diversions, temperature, and precipitation before we present the results from the diversion comparison to SWSI, PDSI, Palmer's $Z$ index, and SPI. All trend analysis is based on the Mann-Kendall nonparametric statistical trend test as discussed in section 4 .

\subsection{Trend Analysis on Temperature}

[29] A review of temperature records from 10 climate stations across the Snake River Plain (shown in Table 3) reveal that all stations have seen a significant $(p<0.30)$ annual temperature increase with a highly significant increase $(p<0.10)$ at 9 of the 10 stations. The average annual temperature increase over this period (1971-2005) is $1.4^{\circ} \mathrm{C}$ or $0.4^{\circ} \mathrm{C} /$ decade, based on a linear regression. $\mathrm{A}$ review of long-term temperature records at the Jerome and Nampa weather stations indicate that the greatest temperature increase has occurred during this period, as shown in Figure 6. The last decade of temperature measurement (1996-2005) within this study show an increase of $1.0^{\circ} \mathrm{C}$ and $1.2^{\circ} \mathrm{C}$ over the mean annual temperature between 1906 and 1985, at the two stations, respectively.

[30] As shown in Table 3, all monthly temperature trends are positive, with the month of January having the greatest temperature increase, on average $3.3^{\circ} \mathrm{C}$. The magnitudes of these increases are based on the beginning and end of the trend lines. The month with the most significant temperature increase was March where all stations, except Pocatello, had a highly significant trend. It should be noted, however, that Pocatello was the station that showed the least temperature increase. Also Pocatello was one of the three stations where trends were based on raw station data. The other two "raw" data stations where trends were analyzed matched more closely with their nearest neighbors (compare Dubois with Ashton, and Boise with Nampa). Interestingly some months like February, June, and November had almost no significant temperature trends. A review of seasonal temperatures indicate that the season with the most significant temperature increase was the spring season (March, April, and May, or MAM) followed by summer (June, July, and August, or JJA). While the uncertainty associated with temperature records at the $2 \mathrm{~m}$ level, site exposure, land cover changes, and site relocations call into question the precision of climate trends at individual stations [Pielke et al., 2007]. The remarkable similarity in the magnitude and significance of climate trends between raw and corrected data at stations across the basin gives some confidence that we have correctly identified a warming trend across the Snake Plain, especially in spring from 1971 to 2005 . The advancement of spring in the North America is confirmed not only by temperature records, but also by biologic indicators and streamflow timing [Rosenzweig et al., 2008; Stewart et al., 2005; Clark, 2010].

[31] Since January is the coldest month of the year it is a critical month for snow accumulation in the plain. Thirtyfive years ago, in the western portion of the Snake River Plain at the Boise, Nampa, and Parma climate stations maximum winter temperature hovered around freezing. Now daily average temperatures are beginning to regularly exceed the freezing point. Between 1994 and 2005 the average daily temperature exceeded $0^{\circ} \mathrm{C}$ in 9 out of 12 years at the Parma Experiment Station as shown in Figure 7. (The consideration of the Parma snow record, versus that of the USHCN stations, was due to the incompleteness of snow records for the Nampa and Payette stations. Parma was not included in the temperature trend analysis because of incomplete temperature records.) This temperature rise might have contributed to an increase in rainfall and a 

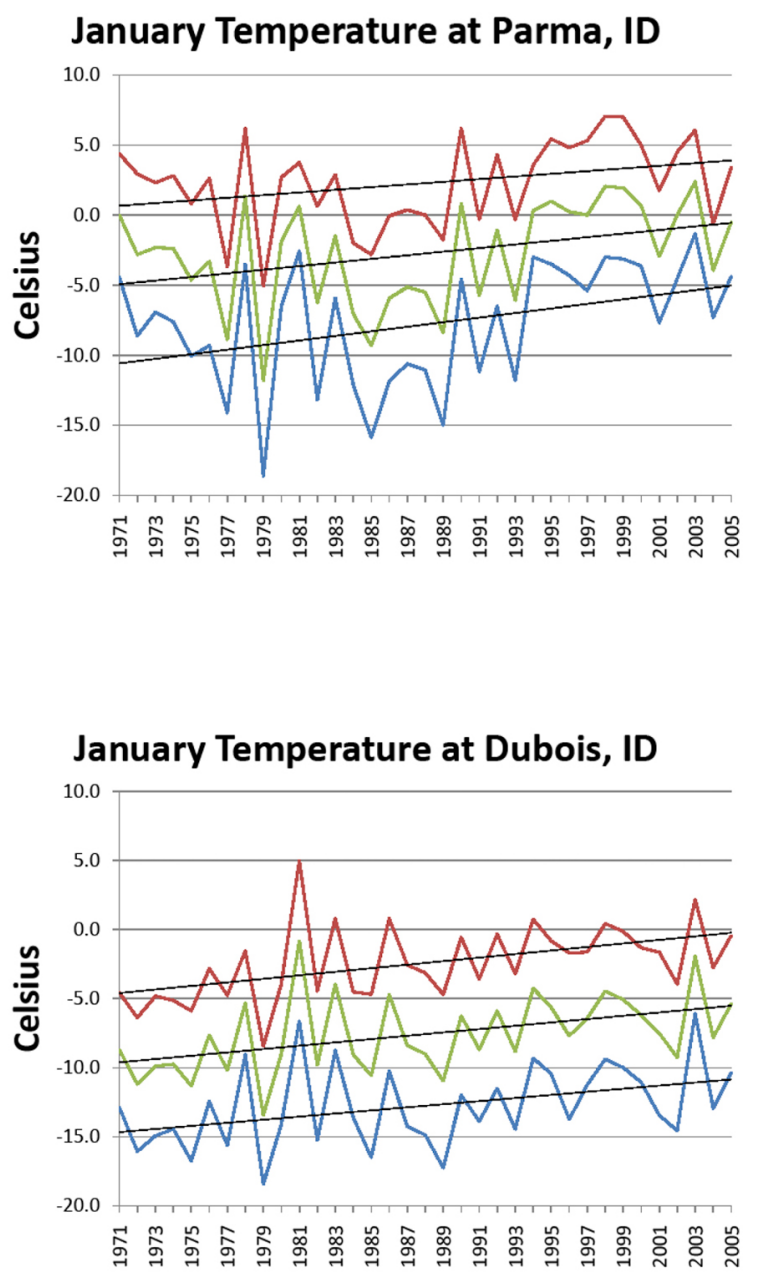

Figure 7. Trends for the average monthly temperature (red), average daily maximum temperature (green), and average minimum daily temperature (blue) for the month of January at the (top) Parma and (bottom) Dubois weather stations from 1971 to 2005 .

decrease in the amount of snowfall accumulation in the western Snake River Plain. At the Parma weather station the number of days with snowfall greater than $25 \mathrm{~mm}$ fell from an average of 17.6 days (1971-1993) to 5.2 days (19942005) in January and from 7 days (1971-1993) to 2 days (1994-2005) in February. This is despite the fact that the second period (1994-2005) included the very wet years of the late 1990s. Total snowfall and maximum monthly depth of snow accumulation also fell significantly at the Parma weather station. In the eastern Snake River Plain represented by weather stations at Dubois and Pocatello, where maximum winter temperatures were still mostly below the freezing point in January and February there was no marked change in the number of days with snow greater than $25 \mathrm{~mm}$, total monthly snow accumulation, or total monthly snowfall. Figure 7 shows the average monthly minimum daily temperature and maximum daily, as wells as, the average daily temperature from 1971 to 2005 . A study of climate change by Salathé et al. [2008] that modeled local responses to climate change in the Northwest, showed that the most significant increases in winter temperatures in the Northwest have occurred, and will continue to occur in areas, like the Snake River Plain, where the number of days with snow cover are declining.

[32] The highly significant spring temperature trends in the months of March and April indicate a potential lengthening of the growing season as identified by Christidis et al. [2007]. A trend test on the minimum daily average temperature for the months of April and May are highly significant at 4 of the 5 highest stations (Pocatello being the exception). At these stations the April minimum daily temperature is regularly beginning to exceed the freezing point. This warming in spring has important implications for beginning of season surface water irrigation trends.

\subsection{Precipitation Trends}

[33] Interannual monthly precipitation variability is high across the Snake River basin, making the detection of precipitation trends difficult. The Mann-Kendall trend test revealed that there were few significant precipitation trends at either the annual or monthly scales. In months where trends did exist, April and May were always positive, while the rest of the months were negative. These trends showed no regional bias. The only consistent seasonal trend at almost all stations was a significant decline in fall (September, October, and November, or $\mathrm{SON}$ ) precipitation.

\subsection{Canal Diversion Trend Analysis}

[34] Not surprisingly, we found that the decline in historic annual diversions is highly significant for most canals in the Snake River Plain. The decline in natural flow during this period adversely impacted the filling of reservoirs, as indicated by a review of the IDWR's monthly reservoir storage records (not shown here). The decline in annual diversions was an obvious result of declines in storage and natural flow, the two main sources of surface water irrigation. However, not all of the decline in diversions is necessarily related to declining supply. As seen by the larger than usual decline in surface water diversions from the Teton River, after the collapse of the Teton Dam in 1976 [Stene, 1997]. What is surprising is that despite a significant decline in annual diversions, spring diversion either remained constant or, in many cases, increased significantly.

[35] To put the declining diversion trends in perspective we calculated both the annual and total decline of diversions for each major basin: the Henry's Fork, Snake River above Milner, and the combined Boise-Payette basin. The total decline in diversions over 35 years in the eastern most irrigation region containing the Henrys Fork, Falls River, and Teton River is about $430,000 \mathrm{~m}^{3}$. The middle of the Snake River basin represented by diversions from main stem of the Snake River has seen surface water diversions decline by roughly $1,940,000 \mathrm{~m}^{3}$, while the western end of the plain has seen irrigation diversions decline by $260,000 \mathrm{~m}^{3}$. It should be noted that complete diversion records were missing on the New York Canal and on the Payette River, so that the decline in diversion from the western portion of the basin are incomplete, and represents only diversions from the Boise River excluding the New York Canal. Except for diversions on the New York Canal that are represented by diversions 515 to 530 and the Payette River, which have incomplete diversion records, the only basin with mixed annual diversion trends is Falls River. While the months of 
Table 4. Emergence Date for Major Idaho Crops at Various Agrimet Weather Stations

\begin{tabular}{lcccc}
\hline $\begin{array}{c}\text { Agrimet } \\
\text { Station } \\
\text { Elevation }\end{array}$ & $\begin{array}{c}\text { Ashton, } \\
1615 \mathrm{~m}\end{array}$ & $\begin{array}{c}\text { Aberdeen, } \\
1341 \mathrm{~m}\end{array}$ & $\begin{array}{c}\text { Twin Falls, } \\
1195 \mathrm{~m}\end{array}$ & $\begin{array}{c}\text { Nampa, } \\
824 \mathrm{~m}\end{array}$ \\
\hline Alfalfa & 1 May & 20 March & 10 March & 5 March \\
Spring Grain & 15 May & 15 April & 20 March & 5 March \\
Potatoes & 10 June & 5 June & 10 May & 1 May \\
\hline
\end{tabular}

June, July, and August generally follow the trend of declining annual diversions, April diversions (and May diversions in higher-elevation eastern basins) tended to have either neutral or increasing diversion trends. May diversion patterns are discussed in the next paragraph followed by a discussion of April trends.

[36] While annual diversions have fallen sharply, the beginning-of-season irrigation trends are rising. In the highest-elevation portion of the basin, corresponding to the Dubois and Ashton climate stations, the beginning of season irrigation occurs in May. As one moves from east to west, and down in elevation, across the plain, the growing season becomes longer and May diversions switch from positive to neutral below Heise to mostly negative below Blackfoot, while April diversions remain positive. This change in diversion trends is most likely not related to longitudinal distance from source, as to start of the growing season, which as shown in Table 4 varies significantly as elevation decreases across the plain from east to west. Also the source of the Heise diversions is the South Fork of the Snake River, which is not impacted by diversions from the Henry's Fork, and diversions from the Boise River (in which all May diversions are negative) are uninfluenced by diversions in the eastern plain.

[37] April diversion trends have an interesting pattern on the Snake River and Boise River, in that the upstream diversion trends tend to be positive, while downstream diversion trends tend to be neutral. We believe this could be the result of downstream users having a more reliable irrigation supply. The reliance of downstream users on return flows is well documented on the Boise River [U.S. Bureau of Reclamation, 2009]. A comparison of diversions to SWSI in both the lower Snake River and Boise River, indicate that these entities are rarely water short. The reason downstream users are least impacted by water shortages on the Snake is that they rely more on storage, while upstream users on the Snake typically depend more on natural flow [Stene, 1997]. Implying that perhaps the more a canal company is prone to shortage the more their users may rely on the early irrigation. It should be noted that both on the Snake and the Boise rivers the early season (April) diversions, even if neutral contrast to the highly significant decline of most mid and late season diversions. The difference in sign of early season diversions compared to annual diversions has important implications in understanding how increasing temperature impacts irrigation diversions within the Snake River basin and will be shown by the comparison of SWSI and PDSI to diversions discussed below.

\subsection{Diversion Comparison to Supply and Climatic Indices}

[38] The results of comparing diversions to surface water supply represented by SWSI and soil moisture represented by PDSI are shown below. From our analysis it appears that surface water diversions are demand driven in the springtime, and supply driven during the remainder of the irrigation season. Peak runoff from the mountain snowpack occurs during the late spring and early summer providing ample supply at the beginning of the irrigation season. During the later part of the irrigation season supply becomes more limited.

\subsection{Comparison of Diversions With SWSI}

[39] Figure 8 shows the trend in annual diversions over the period of study (1971-2005) in the Burgess Canal located on the Heise-Lorenzo reach of the Snake River. Overall the trend in diversions declined by about $3,200 \mathrm{~m}^{3} / \mathrm{yr}$. The decline of diversions on the Burgess Canal would appear to be mainly the result of the extensive 1988-1993 drought as well as the 2000-2005 droughts as evidenced by the rebound in diversions during the wet period in the late 1990s. The recent multiyear droughts, as noted earlier, decreased both the natural flow and storage water available for irrigators. The rebound of irrigation during the late 1990s on most canals indicates that water conservation through sprinkler conversions may not have had a significant impact on the amount of water diverted when it is available.

[40] Figure 9 shows the correlation of diversions to SWSI on a monthly basis on the Burgess Canal. The results described here apply to most of the canals in the study. Correlation between diversions and supply, represented by SWSI, did not conform to the piecewise function for the months of April and May. At the beginning of the study period from 1971 to 1987 there were only 3 years in which diversions occurred in April on the Burgess Canal. After 1987 diversions occurred in two thirds of the remaining 18 years. The increased April diversions may be an indication of the lengthening of the growing season, which in the western United States has occurred mainly in spring [Christidis et al., 2007]. The lack of any significant trend in diversions based on supply in April and May, as seen in Figures 9a and 9b, indicates that diversions in these months are not supply limited. The weak inverse relationship of May diversions to supply indicate that surface water diversion (and thus irrigation) in the early part of the year were driven more by need than supply. Just as Alfaro et al. [2005] found that groundwater irrigation begins earlier in dry years, it appears that surface water irrigation begins earlier in years with less supply, which typically would be drier years. This understanding

\section{Burgess Canal}

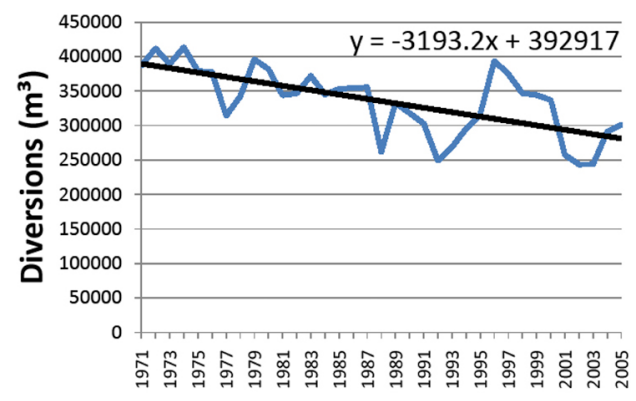

Figure 8. Annual diversions of the Burgess Canal located below Heise in climate division 9 from 1971 to 2005. 
(a)

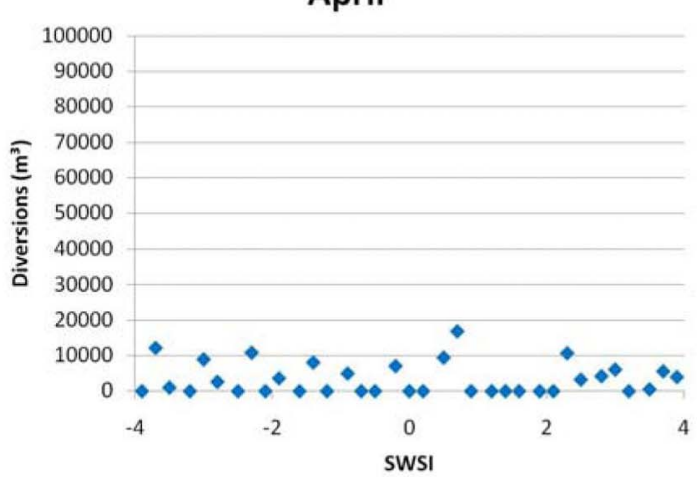

(c)

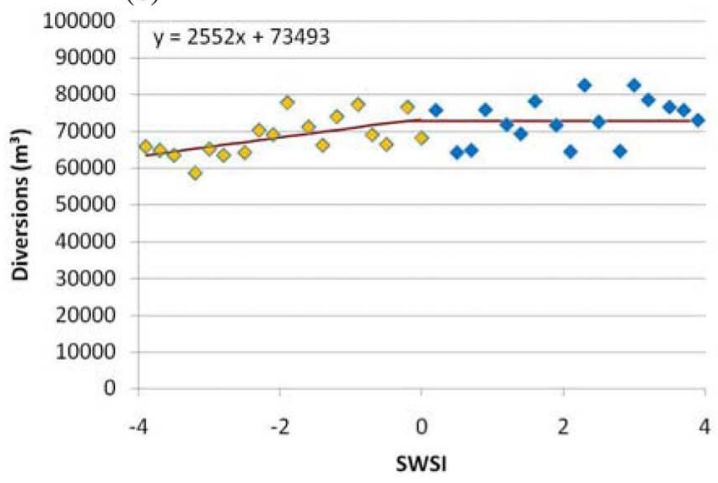

(e)

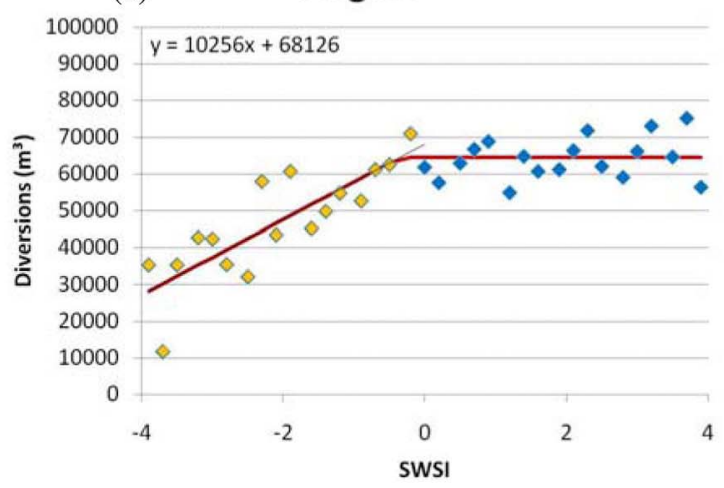

(b)

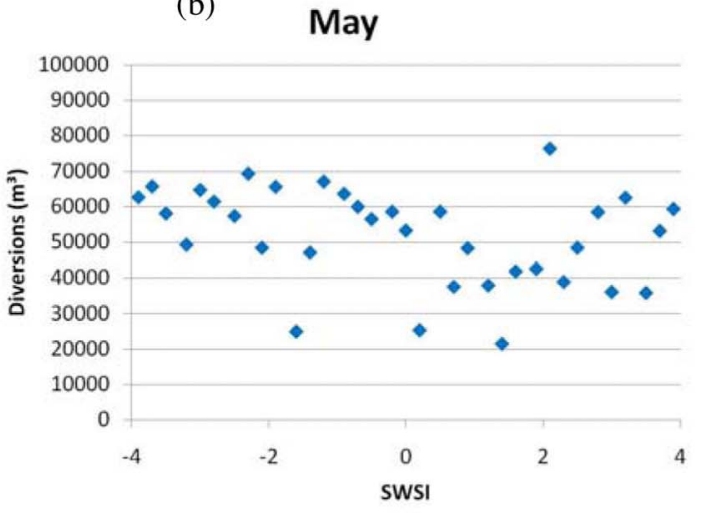

(d)

July

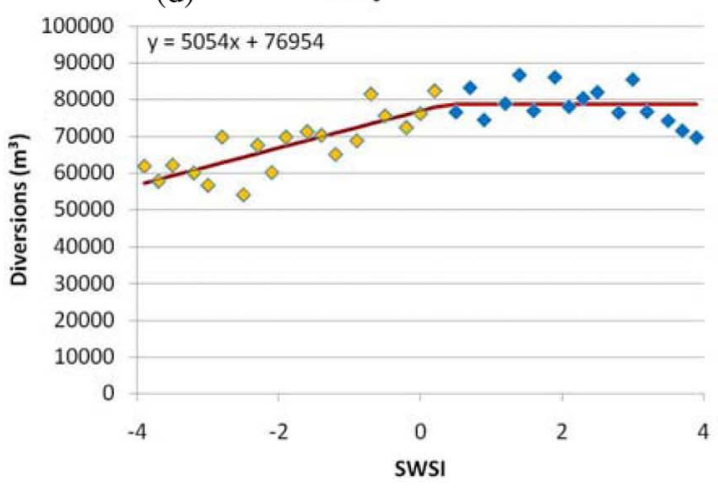

(f) September

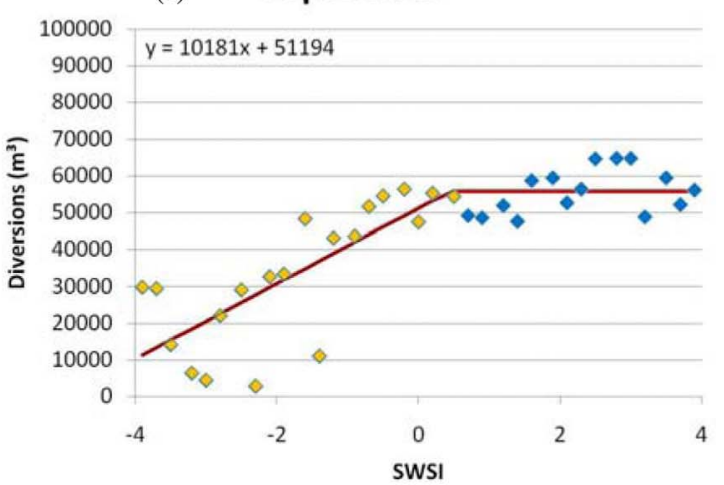

Figure 9. (a-f) Correlation of Burgess Canal diversions to the SWSI index in climate division 9.

was supported by investigating the correlation of PDSI and Palmer's $Z$ index to spring diversions as discussed later in the paper. After May, diversions correlate with supply according to the piecewise function described earlier, indicating that for the remainder of the year diversions were constrained by supply. As would be expected, the rising limb of the piecewise function tended to become progressively steeper between June and September as reservoir storage and natural flow become depleted late in the season during years with low supply.

\subsection{Correlation of Diversions With PDSI, the $Z$ Index, and SPI}

[41] We found that in a heavily irrigated semiarid region like the Snake River Plain, where summer precipitation is almost always inadequate to meet the crop water demand, PDSI, $Z$ index, and SPI, have almost no correlation (using the Spearman's rank correlation coefficient) with midseason and late season surface water diversions. However, during the first month of irrigation (usually April), both March and April PDSI values, as seen in Table 5, provide some limited correlation. Both the March and April Palmer $Z$ index shows significantly greater correlation and when combined provide the greatest correlation. The SPI index also provides significant but generally less correlation than the $Z$ index. Also the significance of the SPI varies based on the period of calculation. March, April, and May SPI were correlated for this research based on 1 month, 2 month, 3 month, and 6 month time periods. There was no consistent correlation between April 1 month SPI and diversions, but generally significant 
Table 5. Correlation of PDSI, $Z$ Index, and April 2 Month, 3 Month, and 6 Month SPI to April Diversions From 1971 to 2005

\begin{tabular}{lccccc}
\hline & April & MA- & & & \\
& PDSI & Zndx & A-SPI2 & A-SPI3 & A-SPI6 \\
\hline Upper Snake (division 9) & -0.55 & -0.79 & -0.56 & -0.54 & -0.67 \\
Anderson & & -0.80 & -0.54 & -0.53 & -0.60 \\
Burgess & -0.81 & -0.59 & -0.61 & -0.78 \\
Dry Bed (19) & -0.65 & -0.58 & -0.62 & -0.69 \\
Clark and Edwards & -0.65 & -0.58 & -0.62 & -0.69 \\
East Labele & -0.71 & -0.64 & -0.58 & -0.68 \\
Rigby & -0.50 & - & - & - \\
West Labele and Long Island & -0.67 & - & - & -0.64 \\
Butte and Market Lake & -0.54 & - & - & - \\
Idaho & 0.72 & - & - & -0.61 \\
Snake River Valley & -0.64 & - & - & - \\
Blackfoot & -0.73 & - & - & - \\
Peoples & -0.80 & -0.64 & -0.62 & -0.69 \\
Aberdeen-Springfield & -0.53 & - & - & - \\
Central Snake (division 7) & -0.42 & -0.74 & - & - & - \\
Minidoka & -0.83 & -0.64 & -0.59 & -0.63 \\
Burley & -0.84 & -0.63 & -0.55 & -0.61 \\
Milner-Gooding & -0.71 & -0.57 & - & - \\
T. F. North Side & -0.63 & - & - & - \\
T. F. Main Canal & -0.80 & -0.59 & -0.54 & -0.59 \\
Western Valleys (division 5) & -0.62 & -0.84 & -0.66 & -0.65 & -0.63 \\
$\quad$ Boise River & -0.70 & -0.57 & -0.51 & -0.51 \\
Ridenbaugh & -0.66 & -0.52 & - & - \\
Phyllis & -0.85 & -0.68 & -0.68 & -0.67 \\
Black Canyon N. & -0.79 & -0.64 & -0.56 & -0.50 \\
Black Canyon S. & & & & \\
\hline & & &
\end{tabular}

correlation at either the 2 month, 3 month, or 6 month April SPI value. Table 5 compares the combined $Z$ index and SPI correlation to all April diversions (all diversions, in Appendix A, with complete record from 1971 to 2005 were summed by climate division) by climate division and for a few specific canals. The significant level of correlation of the 2 month April SPI as shown in Table 5 is typically greater than the 3 month SPI, indicating that combined precipitation of March and April tends to have the greatest impact on April diversions. Though total wintertime precipitation also appears to have some impact on diversions in climate division 9 (diversions above Aberdeen in Table 5).

[42] While not shown here, canals that began irrigation in May rather than April, typically showed highly significant correlation to both the April and May $Z$ index (especially an April plus May combined $Z$ index) and the SPI. While the results were inconsistent, our research indicated that in some instances the SPI index might be used to predict second month irrigation (May) diversions.

[43] The correlation of PDSI, and especially the $Z$ index, to first month diversions indicates that at the beginning of the season, the amount of surface water diverted corresponds to the amount of water needed to restore moisture to the soil column. As expected, during wet years represented by positive PDSI values diversions were low, while during drier years represented by negative PDSI values diversions were higher since more water was needed to replenish depleted soil moisture. Figure 10 shows an example of $Z$ index and 2 month April SPI correlation to diversions from climate divisions 5, 6, and 7. The weaker and less consistent correlation of the SPI index, is most likely due to the SPI only representing anomalies in precipitation, not in temperature or ET values [Hu and Willson, 2000; Quiring and Papkryiakou, 2003]. The importance of the temperature trend can be seen in a Mann-Kendall analysis of trends in the $Z$ index and SPI index from 1971 to 2005 . A Mann-Kendall test on 2 month April SPI values leads to no significant trends even at the $(p<$ 0.30 ) level of significance, but a Mann-Kendall test of the combined March plus April $Z$ index has a significant negative trend with a significance level of $(p=0.047),(p=0.172)$, and $(p=0.083)$ for climate divisions 5,7 , and 9 , respectively.

\section{Discussion}

[44] In considering the impacts of climate change on surface water diversions in the Snake River Plain during the period (1971-2005), it is important to recognize the difference between interannual climate variability and climate change. Precipitation records, for example contain very few long-term trends. As Mote and Salathé [2010] point out the detection of significant changes in precipitation are likely to be difficult, well into the next century, due to climate variability. On the other hand the temperature record has highly significant trends, at the annual, seasonal, and monthly scales. This trend would seem to be largely a product of long-term, and most likely human-induced, climate change. The loss in snow cover in the western portion of the plain, that is likely to migrate eastward [Salathé et al., 2008], as the temperature warms, is mostly a product of the significant increase in January temperatures. The rise in springtime temperatures and corresponding trend of earlier diversions also corresponds to the highly significant increase in springtime temperature, causing a lengthening of the growing season [Christidis et al., 2007]. The superior correlation of a combined Palmer's $Z$ index to SPI indicates that first month diversions in the Snake Plain are most likely driven by anomalous soil moisture conditions that are the result of both temperature and precipitation anomalies, not just precipitation anomalies.

[45] We hypothesize that the physical mechanism driving increased spring diversions during the study period is mainly the increase in springtime temperatures. The springtime SPI trend ( 2 month April SPI) trends and precipitation trends are either positive or insignificant while temperatures trends for both temperature and the $Z$ index are all significant. Because the $Z$ index is a measure of moisture conditions the significant $Z$ index trends indicate that the rise in temperature during the period from 1971 to 2005 has caused increased soil moisture deficits in the springtime.

[46] Interestingly the rise in temperatures during the peak of the growing season, has had little discernable impact on surface water diversions. The flat limb on the summertime SWSI versus diversion graphs captures both diversions in the high-supply years of the 1970s and late 1990s. Any impact of rising temperatures on summertime surface water diversions is masked by the fact that the amount diverted each month is heavily dependent on supply. Future studies at the farm scale of application, might be able to better capture the impact of rising temperature on crop water demand.

[47] The implications of this research for water resource management in the Snake River basin, is that long-term planning for climate change should focus on climate impacts to supply (e.g., snowpack) and the lengthening of the irrigation season. The impact of changes in supply due to climate change should use the flat limb of the SWSI index to indicate the amount of water farmers would like to divert given adequate supply in order to provide canal companies and water 
(a)
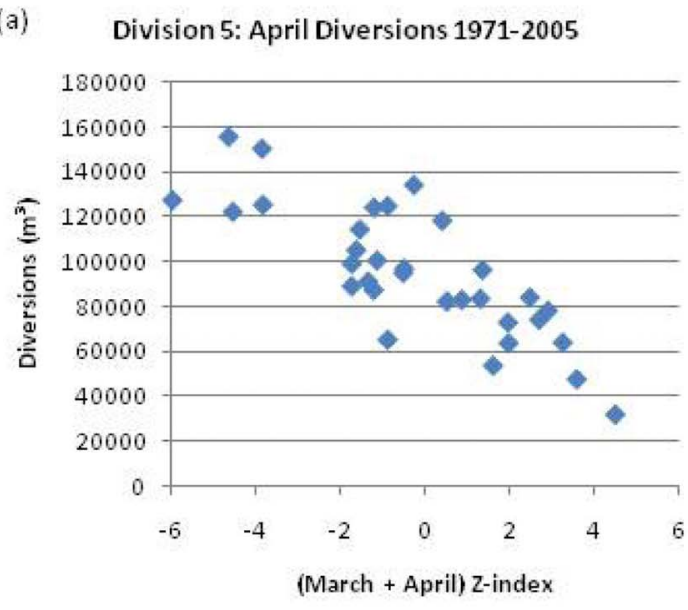

(c)

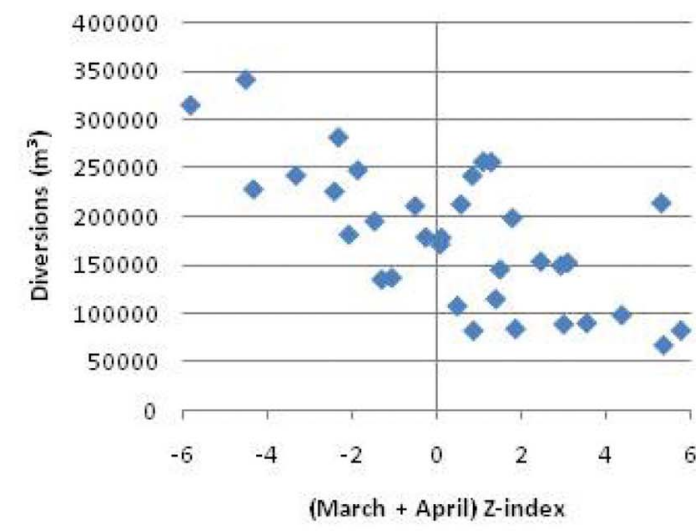

(e) Division 9: April Diversions 1971-2005

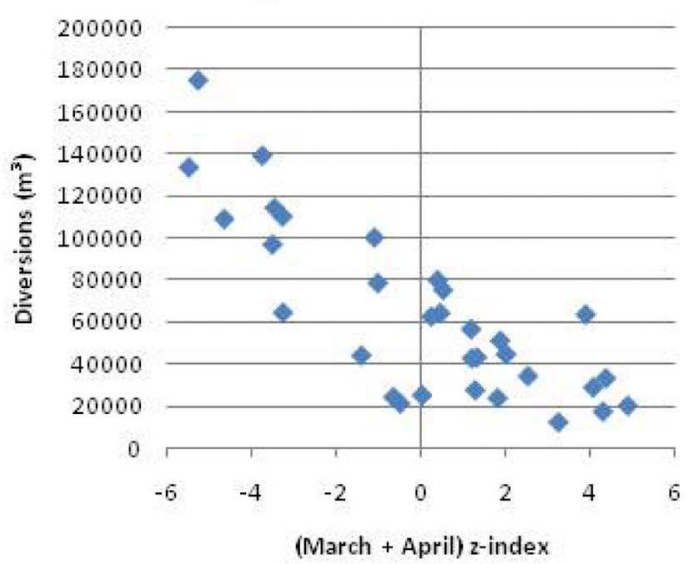

(b)

Division 5: April Diversions 1971-2005

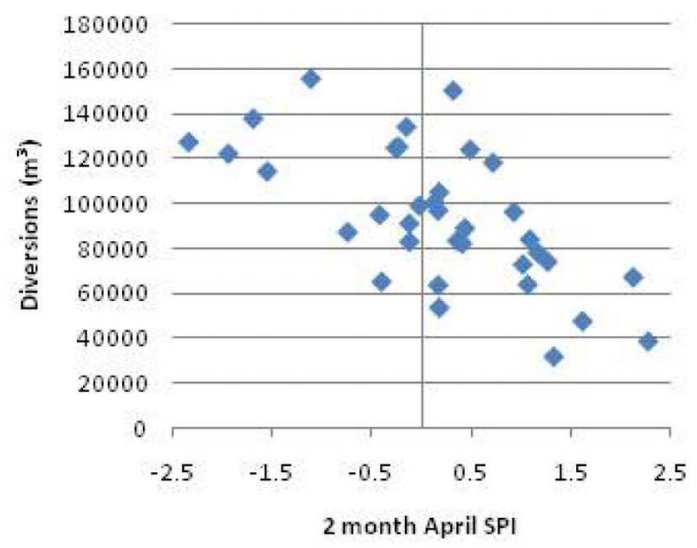

(d)

Division 7: April Diversions 1971-2005

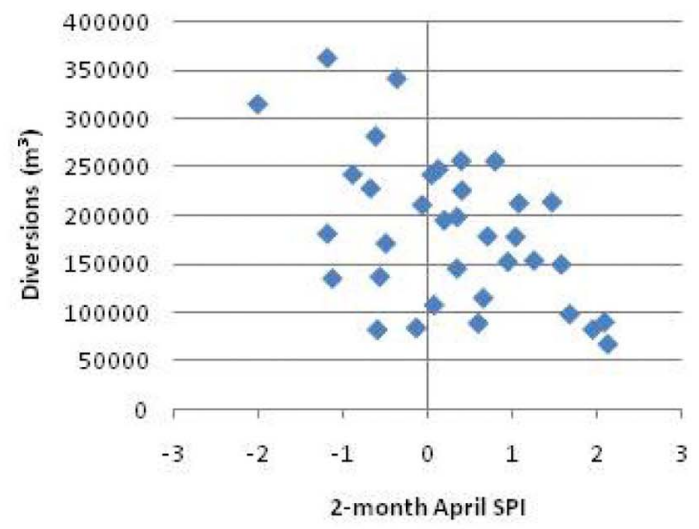

(f)

Division 9: April Diversions 1971-2005

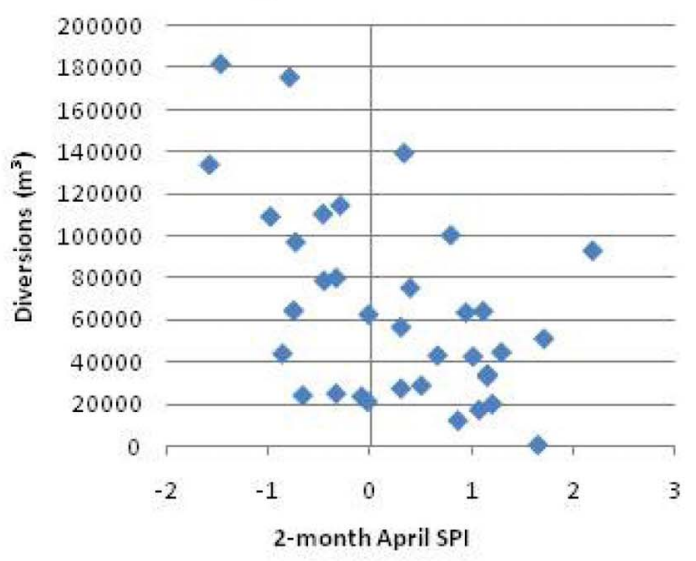

Figure 10. Correlation of drought indices to 1971-2005 diversions: (a) March and April Z index versus division 5 diversions, (b) 2 month April SPI versus division 5 diversions, (c) March and April Z index versus division 7 diversions, (d) 2 month April SPI versus division 7 diversions, (e) March and April $\mathrm{Z}$ index versus division 9 diversions, and (f) 2 month April SPI versus division 9 diversions.

resource managers and irrigators a sense of how climate change may impact the reliability of surface water supply. Use of average diversions over the last 15 years, is likely to underestimate diversion demand during high-supply years.
On the annual scale of predicting water demand, this research indicates that Palmer's $Z$ index in March could be used to estimate April diversions. Such estimates could help water 
Table A1. Diversion Locations Where the Mann-Kendall Trend Test Was Applied

\begin{tabular}{|c|c|c|c|}
\hline Diversion Source & Diversion & Canals & Data Limitations \\
\hline \multirow[t]{6}{*}{ Falls River } & 010 & Yellowstone, Marysville & \\
\hline & 015 & Miscellaneous diversions Squirrel to Chester & \\
\hline & 020 & Farmers Own, McBee, Silkey & \\
\hline & 030 & Enterprise & \\
\hline & 035 & Fall River & \\
\hline & 040 & Chester, Curr & \\
\hline \multirow[t]{5}{*}{ Henry's Fork } & 045 & Dewey, Last Chance & \\
\hline & 050 & St. Anthony Union & \\
\hline & 060 & Farmer's Friend, Twin Groves, Salem Union & \\
\hline & 070 & Egin Canal, St. Anthony Union Feeder, Independent & \\
\hline & 080 & Consolidated Farmers & \\
\hline \multirow[t]{4}{*}{ Teton River } & 090 & Siddoway, Teton Irrigation, Woodmansee-Johnson & $\begin{array}{l}\text { Teton Dam collapse of } \\
1976 \text { may bias trends }\end{array}$ \\
\hline & 100 & Wilford, Pioneer, Stewart & $\begin{array}{l}\text { Teton Dam collapse of } \\
1976 \text { may bias trends }\end{array}$ \\
\hline & 110 & Pincock-Byington & $\begin{array}{l}\text { Teton Dam collapse of } \\
1976 \text { may bias trends }\end{array}$ \\
\hline & 120 & City of Rexburg, Rexburg Irrigation & $\begin{array}{l}\text { Teton Dam collapse of } \\
1976 \text { may bias trends }\end{array}$ \\
\hline \multirow[t]{9}{*}{ Snake River, Heise to Lorenzo } & 135 & Anderson & \\
\hline & 137 & Farmers Friend, Enterprise, Salem Union & \\
\hline & 140 & Harrison, Boomer and Rudy & \\
\hline & 145 & Burgess & \\
\hline & 150 & Ross and Reid, Lowder and Jennings, & \\
\hline & & $\begin{array}{l}\text { Clark and Edwards, Labele and Long Island, } \\
\text { Parks and Lewisville, North Rigby, }\end{array}$ & \\
\hline & & White, Bramwell, Ellis, Mattson Craig & \\
\hline & 160 & Sunny Dell, Lenroot, Reid, & \\
\hline & & $\begin{array}{l}\text { Texas Feeder, Bannock-Jim, Hill-Petinger, } \\
\text { Nelson-Corey }\end{array}$ & \\
\hline \multirow[t]{8}{*}{ Snake River, Lorenzo to Blackfoot } & 170 & Butte and Market Lake & \\
\hline & 180 & $\begin{array}{c}\text { Kennedy, Great Western, Porter, } \\
\text { Woodville, Bear Trap }\end{array}$ & \\
\hline & 190 & Idaho & \\
\hline & 200 & Snake River Valley & \\
\hline & 220 & Blackfoot, Corbett, Nielsen-Hansen & \\
\hline & 230 & New Lava & \\
\hline & 240 & Peoples & \\
\hline & 242 & Aberdeen-Springfield & \\
\hline \multirow[t]{2}{*}{ Blackfoot River } & 248 & Fort Hall Main & \\
\hline & 249 & Fort Hall North & \\
\hline \multirow[t]{7}{*}{ Snake River, Blackfoot to Milner } & 253 & Fort Hall Mauchad & \\
\hline & 260 & Burley Southside & \\
\hline & 270 & Minidoka Northside & \\
\hline & 280 & Twin Falls Southside & \\
\hline & 285 & Northside Minidoka Pump & \\
\hline & 290 & Milner-Gooding & \\
\hline & 300 & Twin Falls North Side & \\
\hline \multirow[t]{20}{*}{ Boise River } & 505 & Penitentiary & \\
\hline & 515 & New York 2-6 & 1971-1999 \\
\hline & 520 & Mora & 1971-1999 \\
\hline & 525 & New York 6-10 & 1971-1999 \\
\hline & 530 & Lake Lowell & $1971-2003$ \\
\hline & 535 & Ridenbaugh & \\
\hline & 540 & Bubb, Rossi Mill, Boise City & \\
\hline & 545 & Settlers, Davis & \\
\hline & 550 & Thurman Mill & \\
\hline & 555 & Farmers Union & \\
\hline & 560 & New Dry Creek, Ballentyne, Middleton, Little Pioneer & \\
\hline & 562 & Lemp, Warm Springs, Graham-Gilbert, & \\
\hline & & $\begin{array}{c}\text { Conway-Hamming, Aiken, Mace-Catlin, Mace-Mace, } \\
\text { Hart-Davis, Seven Suckers }\end{array}$ & \\
\hline & 564 & Phyllis & \\
\hline & 568 & Canyon County & \\
\hline & 570 & Caldwell Highline & \\
\hline & 574 & Riverside, Pioneer Dixie & \\
\hline & 576 & Sebree, Campell, Siebenberg & \\
\hline & 580 & $\begin{array}{c}\text { Eureka2, Upper Center Point, Lower Center Point, } \\
\text { MacManus and TR }\end{array}$ & \\
\hline & 585 & $\begin{array}{l}\text { Bowman and Swisher, Baxter, Andrews, Mammon, } \\
\text { Haas, Parma, Island Highline, McConnell }\end{array}$ & \\
\hline \multirow[t]{2}{*}{ Payette River } & 620 & Northside Black Canyon & $1971-2002$ \\
\hline & 625 & Southside Black Canyon & $1971-2002$ \\
\hline
\end{tabular}


Table A1. (continued)

\begin{tabular}{|c|c|c|c|}
\hline Diversion Source & Diversion & Canals & Data Limitations \\
\hline & 640 & $\begin{array}{c}\text { Last Chance, Farmers Cooperative, Gill Slough, } \\
\text { Smith Ditch, Enterprise, Bilbrey, Reed, } \\
\text { Kesgard-Tschudy, O’Turley Ditch, Sietz, Woods, } \\
\text { Payette River Ranch }\end{array}$ & 1993-2005 \\
\hline & 655 & $\begin{array}{l}\text { Patton-Riggs Ditch, Noble, Rosebury, Stewart, } \\
\text { Nichols, Pulley Ditch, Rasmussen, Pump Cooper }\end{array}$ & 1993-2005 \\
\hline & 670 & $\begin{array}{c}\text { Upper Accord, Lower Accord, Nesbitt-McFarland, Barker, } \\
\text { Burt, Hendrickson Pump, Pence Pump, } \\
\text { Lower Payette Canal, Island Farms Ditch, } \\
\text { Johnson Ditch, Simplot Pump, B May Pump }\end{array}$ & 1993-2005 \\
\hline
\end{tabular}

managers plan reservoir operations using forecasts of diverters demands with near-term forecasts.

[48] In order to gain a better understanding of how crop water demand and changes in land use impact surface water diversions, the authors suggest further research that perhaps involves fewer diversion entities and includes a more detailed look at land use changes, canal seepage, and water rights. If a data set of land use, canal seepage, and irrigation practices at the farm scale could be assembled these records could help close the water budget and identify how increased efficiency of irrigation may be helping farmers adapt to climatic change. Also the establishment of flux measurement and soil moisture monitoring stations that could confirm results of modeled data would be highly beneficial, to the study of climate impacts in the basin.

\section{Conclusions}

[49] While we cannot, at this point, differentiate how much of the hydrologic change in the Snake River basin has been forced by anthropogenic sources versus natural climate change, we are able to detect how climate attributes are changing, and how these changes are influencing surface water demand. The results of this research lead us to believe that the marked decline in irrigation during the last three and a half decades is at least partly the result of a decline in water supply caused by declining natural flow [Clark, 2010]. Since this decline is in part the result of drought, it is likely that if we enter a period with higher streamflows, we will see an increase in annual diversions. However, the increase in diversions in the midirrigation and late irrigation season are limited by water availability, water resource infrastructure and the limitations imposed by water rights.

[50] While annual diversions have declined, springtime diversions have had a strong increasing trend within lowelevation and midelevation river reaches in the Snake River basin, that are the result of increasing temperature. Warmer spring time temperatures were resulting in the earlier timing of irrigation within some parts of the basin. In the lowerelevation portions of the basin wintertime temperatures have passed the freezing point resulting in loss of snow cover and earlier snowmelt [Sridhar and Nayak, 2010], which has likely led to greater absorption of solar radiation which leads to drier spring soil moisture conditions. Although there are some limited trends of increased springtime precipitation, spring precipitation has not been able to offset increasingly dry springtime soil moisture conditions. The trend of drier spring soils is likely to continue under a warming climate and spread to the higher-elevation portions of the basin within the next couple decades, should warming continue to occur at the present rate. Both the realization that mid and late summer irrigation diversions do not appear to increase beyond an identifiable threshold and that spring irrigation demand will continue to increase is critical when studying the impacts of climate change on water resources in the Snake River basin.

\section{Appendix A}

[51] Table A1 contains a list of the diversion locations on which the Mann-Kendall trend test was applied for this research. The period of record is noted under "Limited Data" only if incomplete; otherwise, the trend test was performed over the years from 1971 to 2005 .

[52] Acknowledgments. This research is supported by the NSF Idaho EPSCoR Program and by the National Science Foundation under award EPS-0814387. Partial support came from NOAA via the Northwest Climate Decision Support Consortium (www.pnwclimate.org) under award NA10OAR4310218. We would also like to thank Sudhir Goyal from IDWR for his help in understanding the SRPM model and Gary Johnson and Kristyn Scott of the University of Idaho, with whom we collaborated on the SWSI diversion correlation.

\section{References}

Alfaro, E. J., D. W. Pierce, A. C. Steinemann, and A. Gershunov (2005), Relationship between the irrigation-pumping electrical loads and local climate in climate division 9, Idaho J. Appl. Meteorol., 44(12), 1972-1978, doi:10.1175/JAM2315.1.

Alley, W. M. (1984), The Palmer Drought Severity Index: Limitations and assumptions, J. Appl. Meteorol., 23, 1100-1109, doi:10.1175/1520-0450 (1984)023<1100:TPDSIL $>2.0$. CO;2.

Barnett, T. P., and D. W. Pierce (2009), Sustainable water deliveries from the Colorado River in a changing climate, Proc. Natl. Acad. Sci. U. S. A., 106(18), 7334-7338, doi:10.1073/pnas.0812762106.

Barnett, T. P., et al. (2008), Human-induced changes in the hydrology of the western United States, Science, 319(5866), 1080-1083, doi:10.1126/ science. 1152538 .

Bates, B. C., Z. W. Kundzewicz, S. Wu, and J. P. Palutikof (Eds.) (2008), Climate change and water, technical paper, Intergov. Panel on Clim. Change, Geneva, Switzerland.

Bonfils, C., et al. (2008), Detection and attribution of temperature changes in the mountainous western United States, J. Clim., 21(23), 6404-6424, doi:10.1175/2008JCLI2397.1.

Bormann, H. (2011), Sensitivity analysis of 18 different potential evapotranspiration models to observed climatic change at German climate stations, Clim. Change, 104, 729-753, doi:10.1007/s10584-010-9869-7.

Brown, D. P., and A. C. Comrie (2004), A winter precipitation "dipole" in the western United States associated with multidecadal ENSO variability, Geophys. Res. Lett., 31, L09203, doi:10.1029/2003GL018726.

Callendar, G. S. (1938), The artificial production of carbon dioxide and its influence on temperature, Q. J. R. Meteorol. Soc., 64, 223-240, doi:10.1002/qj.49706427503.

Cayan, D. R., A. L. Luers, G. Franco, M. Hanemann, B. Croes, and E. Vine (2008), Overview of the California climate change scenarios project, Clim. Change, 87, suppl. 1, 1-6, doi:10.1007/s10584-007-9352-2. 
Christidis, N., P. A. Stott, S. Brown, D. J. Karoly, and J. Caesar (2007), Human contribution to the lengthening of the growing season during 1950-1999, J. Clim., 20(21), 5441-5454, doi:10.1175/2007JCLI1568.1.

Clark, G. M. (2010), Changes in patterns of streamflow from unregulated watersheds in Idaho, western Wyoming, and northern Nevada, J. Am. Water Resour. Assoc., 46(3), 486-497, doi:10.1111/j.1752-1688.2009.00416.x.

Cook, E. R., D. M. Meko, D. W. Stahle, and M. K. Cleaveland (1999), Drought reconstructions for the continental United States, J. Clim., 12(4), 1145-1162, doi:10.1175/1520-0442(1999)012<1145:DRFTCU>2.0.CO;2.

Cook, E. R., R. Seager, M. A. Cane, and D. W. Stahle (2007), North American drought: Reconstructions, causes, and consequences, Earth Sci. Rev., 81(1-2), 93-134, doi:10.1016/j.earscirev.2006.12.002.

Dai, A., K. E. Trenberth, and T. T. Qian (2004), A global dataset of Palmer Drought Severity Index for 1870-2002: Relationship with soil moisture and effects of surface warming, J. Hydrometeorol., 5(6), 1117-1130, doi:10.1175/JHM-386.1

Fall, S., A. Watts, J. Nielsen-Gammon, E. Jones, D. Niyogi, J. Christy, and R. A. Pielke Sr. (2011), Analysis of the impacts of station exposure on the U.S. Historical Climatology Network temperatures and temperature trends, J. Geophys. Res., doi:10.1029/2010JD015146, in press.

Guttman, N. B. (1998), Comparing the Palmer Drought Severity Index and the Standardized Precipitation Index, J. Am. Water Resour. Assoc., 34(1), 113-121, doi:10.1111/j.1752-1688.1998.tb05964.x.

Hamlet, A. F., and D. P. Lettenmaier (1999), Effects of climate change on hydrology and water resources in the Columbia River basin, J. Am. Water Resour. Assoc., 35(6), 1597-1623, doi:10.1111/j.17521688.1999.tb04240.x.

Hidalgo, H. G., et al. (2009), Detection and attribution of streamflow timing to climate change in the western United States, J. Clim., 22(13), 3838-3855, doi:10.1175/2009JCLI2470.1.

Hoerling, M., and J. Eischeid (2007), Past peak water in the Southwest, Southwest Hydrol., 6, 18-19.

$\mathrm{Hu}$, Q., and G. D. Willson (2000), Effects of temperature anomalies on the Palmer Drought Severity Index in the central United States, Int. J. Climatol., 20(15), 1899-1911, doi:10.1002/1097-0088(200012) 20:15<1899::AID-JOC588>3.0.CO;2-M.

Idaho Water Resources Board (1972), River operation studies for Idaho, 98 pp., Boise.

Johnson, G. S., W. H. Sullivan, D. M. Cosgrove, and R. D. Schmidt (1999), Recharge of the Snake River Plain aquifer: Transitioning from incidental to managed, J. Am. Water Resour. Assoc., 35(1), 123-131, doi:10.1111/ j.1752-1688.1999.tb05457.x.

Karl, T. R. (1986), The sensitivity of the Palmer Drought Severity Index and Palmer's Z-index to their calibration coefficients including potential evapotranspiration, J. Appl. Meteorol., 25(1), 77-86, doi:10.1175/15200450(1986)025<0077:TSOTPD>2.0.CO;2.

Kendall, M. G. (1975), Rank Correlation Methods, Griffin, London.

Kenney, D., R. Klein, C. Goemans, C. Alvord, and J. Shapiro (2008), The impact of earlier spring snowmelt on water rights and administration: A preliminary overview of issues and circumstances in the western states, Cent. for Sci. and Technol. Policy Res., Univ. of Colo. at Boulder, Boulder.

Kjelstrom, L. C. (1995), Streamflow gains and losses in the Snake River and groundwater budgets for the Snake River Plain, Idaho and eastern Oregon, U.S. Geol. Surv. Water Resour. Invest. Rep., 03-4244.

Mann, H. B. (1945), Nonparametric tests against trend, Econometrica, 13, 245-259, doi:10.2307/1907187.

Markoff, M. S., and A. C. Cullen (2008), Impact of climate change on Pacific Northwest hydropower, Clim. Change, 87(3-4), 451-469, doi:10.1007/s10584-007-9306-8.

Mabey, D. R. (1982), Geophysics and tectonics of the Snake River Plain, Idaho, in Cenozoic Geology of Idaho, Bull. Idaho Bur. Mines Geol., vol. 26, edited by B. Bonnichsen and R. M. Breckenridge, pp. 139-153, Idaho Dep. of Lands, Moscow, Idaho.

McKee, T. B., N. J. Doesken, and J. Kleist (1993), The relationship of drought frequency and duration to time scales, 8th Conference on Applied Climatology, Am. Meteorol. Soc., 17-22 Jan., Anaheim, Calif.

McKee, T. B., N. J. Doesken, and J. Kleist (1995), Drought monitoring with multiple time scales, 9th Conference on Applied Climatology, Am. Meteorol. Soc., 15-20 Jan., Dallas, Tex.

Menne, M. J., C. N. Williams, and M. A. Palecki (2010), On the reliability of the U.S. surface temperature record, J. Geophys. Res., 115, D11108, doi:10.1029/2009JD013094

Miller, N. L., L. L. Dale, C. F. Brush, S. D. Vicuna, T. N. Kadir, E. C. Dogrul, and F. I. Chung (2009), Drought resilience of the California Central Valley surface-ground-water-conveyance system, J. Am. Water Resour. Assoc., 45(4), 857-866, doi:10.1111j./1752=1688.2009.00329.x.
Mote, P. W., and E. P. Salathé (2010), Future climate in the Pacific Northwest, Clim. Change, 102, 29-50, doi:10.1007/s10584-010-9848-z.

Nash, L. L., and P. H. Gleick (1991), Sensitivity of streamflow in the Colorado basin to climatic changes, J. Hydrol., 125(3-4), 221-241, doi:10.1016/0022-1694(91)90030-L.

Palmer, W. C. (1965), Meteorological drought, Res. Pap. 45, U.S. Weather Bur., Silver Spring, Md.

Payne, J. T., A. W. Wood, A. F. Hamlet, R. N. Palmer, and D. P. Lettenmaier (2004), Mitigating the effects of climate change on water resources in the Columbia River basin, Clim. Change, 62, 233-256, doi:10.1023/B: CLIM.0000013694.18154.d6.

Pielke, R. A., et al. (2007), Unresolved issues with the assessment of multidecadal global land surface temperature trends, J. Geophys. Res., 112, D24S08, doi:10.1029/2006JD008229.

Pierce, D. W., et al. (2008), Attribution of declining western U.S. snowpack to human effects, J. Clim., 21(23), 6425-6444, doi:10.1175/ 2008JCLI2405.1.

Pierce, J. A. S., et al. (2010), A measure of snow: Case studies of the Snow Survey and Water Supply Forecasting Program, pp. 25-42, Nat. Resour. Conserv. Serv, U.S. Dep. of Agric., Salt Lake City, Utah.

Quiring, S. M., and T. N. Papkryiakou (2003), An evaluation of agricultural drought indices for the Canadian prairies, Agric. For. Meteorol., 118(1-2), 49-62, doi:10.1016/S0168-1923(03)00072-8.

Rasmusson, E. M., and T. H. Carpenter (1982), Variations in tropical sea surface temperatures and surface wind fields associated with the Southern Oscillation/El Niño, Mon. Weather Rev., 110, 354-384, doi:10.1175/ 1520-0493(1982)110<0354:VITSST>2.0.CO;2.

Rosenzweig, C., et al. (2008), Attributing physical and biological impacts to anthropogenic climate change, Nature, 453, 353-357, doi:10.1038/ nature 06937.

Salathé, E. P., R. Steed, C. F. Mass, and P. H. Zahn (2008), A high-resolution climate model for the U.S. Pacific Northwest: Mesoscale feedbacks and local responses to climate change, J. Clim., 21(21), 5708-5726, doi:10.1175/2008JCLI2090.1.

Seager, R. (2007), The turn of the century North American drought: Global context, dynamics, and past analogs, J. Clim., 20(22), 5527-5552, doi:10.1175/2007JCLI1529.1.

Slaughter, R. A. (2004), Institutional history of the Snake River 1850-2004, Clim. Impacts Group, Univ. of Wash., Seattle.

Smith, R. P. (2004), Geologic setting of the Snake River Plain aquifer and vadose zone, Vadose Zone J., 3(1), 47-58.

Spearman, C. (1904), The proof and measurement of association between two things, Am. J. Psychol., 15, 72-101. [Republished in Am. J. Psychol., 100, 441-471, doi:10.2307/1422689, 1987.]

Sridhar, V., and A. Nayak (2010), Implications of climate-driven variability and trends for the hydrologic assessment of the Reynolds Creek Experimental Watershed, Idaho, J. Hydrol., 385(1-4), 183-202, doi:10.1016/j.jhydrol.2010.02.020.

Stene, E. A. (1997), The Minidoka Project, Bur. of Reclam., Denver, Colo.

Stewart, I. T., D. R. Cayan, and M. D. Dettinger (2005), Changes toward earlier streamflow timing across western North America, J. Clim., 18(8), 1136-1155, doi:10.1175/JCLI3321.1.

Thornthwaite, C. W. (1948), An approach toward a rational classification of climate, Geogr. Rev., 38, 55-94, doi:10.2307/210739.

Tyndall, J. (1861), On the absorption and radiation of heat by gases and vapours and the physical connection of radiation, absorption, and conduction, Philos. Mag., 22(4), 169-285.

U.S. Bureau of Reclamation (2009), Modeling spatial water allocation and hydrologic externalities in the Boise Valley, Snake River Off., Boise, Idaho.

Wang, A. H., T. J. Bohn, S. P. Mahanama, R. D. Koster, and D. P. Lettenmaier (2009), Multimodel ensemble reconstruction of drought over the continental United States, J. Clim., 22(10), 2694-2712, doi:10.1175/2008JCLI2586.1.

Woodhouse, C. A., J. L. Russell, and E. R. Cook (2009), Two modes of North American drought from instrumental and paleoclimatic data, J. Clim., 22(16), 4336-4347, doi:10.1175/2009JCLI2705.1.

Zhang, Y., J. M. Wallace, and D. S. Battisti (1997), ENSO-like interdecadal variability: 1900-93, J. Clim., 10(5), 1004-1020, doi:10.1175/1520-0442 (1997)010<1004:ELIV>2.0.CO;2.

D. J. Hoekema and V. Sridhar, Department of Civil Engineering, Boise State University, 1910 University Dr., Boise, ID 83725, USA. (vsridhar@ boisestate.edu) 